\title{
7
}

\section{Genetics in Ankylosing Spondylitis - Beyond HLA-B*27}

\author{
Bruno Filipe Bettencourt ${ }^{1,3}$, Iris Foroni ${ }^{1,3}$, Ana Rita Couto ${ }^{1,3}$, \\ Manuela Lima ${ }^{2,3}$ and Jácome Bruges-Armas 1,3 \\ ${ }^{1}$ Serviço Especializado de Epidemiologia e Biologia Molecular, \\ Hospital de Santo Espírito de Angra do Heroísmo \\ ${ }^{2}$ Grupo de Epidemiologia e Genética Humana do Departamento de Biologia da \\ Universidade dos Açores \\ ${ }^{3}$ Genetic and Arthritis Research Group (GARG), Institute for Molecular and Cell Biology \\ (IBMC), University of Porto \\ Portugal
}

\section{Introduction}

The association between HLA-B27 and ankylosing spondylitis (AS) has lead to intense research over the last 4 decades. In the course of this research, it was possible to obtain the best example of an association between a disease and a genetic marker. Genetic factors contribute with more than $90 \%$ for the susceptibility risk to AS being the MHC region, in particularly HLA-B27, the main contributor (Brown, et al., 1996). This evidence is supported by studies using familial cohorts; segregation and twin studies (Brown, et al., 1997; Jarvinen, 1995; Rubin, et al., 1994).

The advent of genotyping technologies, in particular the use of genome-wide linkage studies (GWLS) and whole-genome association studies (WGAS), allowed a wider view of the genetic factors related to AS and supported the presence of non-MHC genetic AS susceptibility factors. The first whole genome wide linkage study identified numerous loci in linkage with the disease, on chromosomes 1p, 2q, 6p, 9q, 10q, 16q, and 19q (Laval, et al., 2001). These results prompted to an even more intense research on AS and, consequently, the investigation of other areas outside MHC. Later, three other major studies tried to narrow down the chromosome areas first identified (Consortium TASC, 2010; Consortium TASC/WTCCC2, 2011; Consortium WTCCC/TASC, 2007). This way it was possible to identify specific gene regions that would lead to new insights in the mechanisms underlying the disease susceptibility (Table 1). In this chapter we intend to provide an overview of the main genes, other than HLA-B*27, which were identified as been associated to AS during the last decade.

\section{Genes with consistent association to ankylosing spondylitis}

\subsection{Major histocompatibility complex}

At this moment, over 80 subtypes of HLA-B27 (coding and non-coding) are known (http://hla.alleles.org/alleles/class1.html). All variants were originated from the parental 
$\mathrm{B}^{\star 27: 05}$ as a result of different mechanisms, such as point mutation, gene conversion, reciprocal recombination and interlocus gene conversion (Reveille, J D \& Maganti, 2009). The data obtained from studies within same ethnic groups allowed the perception that there are differences in the rank of association of each B27 subtype and AS. The allele HLA$B \star 27: 05$ is the most frequent variant of B27 worldwide, although the frequencies of all the known subtypes diverge when different ethnic groups are compared (Reveille, J D, 2011). For that reason, it has been very difficult to establish a clear ranking of B27 variants and association with AS, that could be applied to all groups (Brown, 2010).

Among European Caucasians, $B^{*} 27: 05$ and $B * 27: 02$ are suggested to be the strongest disease associated variants (Brown, et al., 1996; MacLean, et al., 1993; Reveille, J D, 2011). In Asian cohorts, HLA-B*27:04 was found to be more strongly associated with AS than B²7:05 (Hou, et al., 2007; Liu, et al., 2010; Lopez-Larrea, C, et al., 1995). Other B*27 alleles were already reported in AS cases, namely B*27:01 (Ball \& Khan, 2001), *27:03 (Gonzalez-Roces, et al., 1997), *27:07, *27:08 (Armas, et al., 1999), *27:10 (Garcia, et al., 1998), *27:14, *27:15 (GarciaFernandez, et al., 2001), and *27:19 (Tamouza, et al., 2001).

The information obtained in studies with B27 subtypes confirm this allele as a critical factor on AS susceptibility. However, since it is known that less than $8 \%$ of B27 individuals develop AS (van der Linden, et al., 1984), it is difficult to exclude another gene nearby B27 as the one responsible for the AS susceptibility. The high level of linkage disequilibrium (LD) in the MHC region is a major barrier to the identification of any other possible gene directly involved.

New insights were reached inside $\mathrm{MHC}$, despite all the complexity involving this region. HLA-B60 (B*40:01) was identified as the first non-HLA-B*27 gene strongly associated to AS susceptibility. The first report of this association stated that HLA-B60 was increased among AS patients HLA-B27 positive, in five independent data sets. On the other hand, the studied variant was not increased in HLA-B27 negative patients with AS. A whole view of the obtained data show that the susceptibility to AS is threefold higher in individuals both B27/B60 positive (Robinson, et al., 1989). These findings were later supported by other studies using different cohorts. In a group of UK patients with AS, not only the association strength of B27/B60 positive was confirmed. The presence of HLA-B60 was observed in HLA-B27 negative patients, suggesting that, despite having a much weaker effect, it may function as an AS susceptibility gene independent of HLA-B27 (Brown, et al., 1996). Moreover, in a group of Taiwan Chinese it was confirmed the association of B60 with AS and also, for the first time, an independent association of B61 was found. Both alleles were strongly increased in HLA-B27 negative patients (Wei, et al., 2004). Although all this replications confirming the relationship between HLA-B60 and AS, the same was not seen in Mexican Mestizos where, instead, HLA-B49 was identified as significantly increased in patients with AS (Vargas-Alarcón, et al., 1994).

Another allele, HLA-B*39, has been reported to be increased in HLA-B27 negative White Caucasian and Japanese AS patients (Khan, et al., 1980; Yamaguchi, et al., 1995). The studies that provided this data used small cohorts and consequently it is not possible to state if this is an effective association neither the level of its power. Even so, it was formulated a parallelism between B27 and B $* 39$ components of the peptide-anchoring B pocket as well as peptide-ligand motifs, supporting some potential explanation for the HLA-B27 influence in the development of AS (Yamaguchi, et al., 1995). This results were not confirmed in a cohort 
composed by White Caucasians and Mexican Mestizos (Maksymowych, W P, et al., 2000). The prevalence of AS in Sub-Saharan black Africans is very low, a fact that has been related to the low frequency of HLA-B27 in that region. The allele HLA-B*1403, found exclusively in African or Afro-American populations, was reported in four out of eight AS Togolese patients, a population where HLA-B27 is considered to be virtually absent (Lopez-Larrea, C, et al., 2002). It was the first time that a variant of $B^{\star} 14$ was found to be present in AS patients. However, a confirmation is needed and a mandatory replication of this study in other sub-Saharan populations is still missing. These findings in HLA-B alleles, other than HLA-B27, are not clear enough to understand if there is a direct association with AS or if this is the result of LD with another MHC gene.

Data derived from GWAS for susceptibility loci in AS extended the HLA association in the MHC region between markers D6S276 and DRB1 (Brown, et al., 1998b). This finding has been supported by the results obtained in different ethnic groups (Brown, et al., 1998a; Jaakkola, et al., 2006; Kchir, et al., 2010; Mahfoudh, et al., 2011; Ploski, et al., 1995; SaidNahal, et al., 2002; Sims, A M, et al., 2007). HLA-DRB1 was found to have a strong association with AS. In British patients the level of this association was increased in DR1 homozygotes, a fact that may suggest a B27-independent association, excluding a possible LD effect (Brown, et al., 1998a; Sims, A M, et al., 2007). On the other hand, in French families the association between DR1 and AS seems to be a consequence of LD with HLA-B27 (SaidNahal, et al., 2002). Here, it was reported an excess of transmission of HLA-DR4 to patients, independently of its LD with B27. Together with the lack of transmission of DR4 to HLAB27 positive siblings, this report suggests that the presence of DR4 may contribute to AS simultaneously with B27. The HLA-DR1 is associated to SpA in Mexican patients, however, this finding was not confirmed when only AS patients were analysed (Vargas-Alarcon, et al., 2002). The sample size and the high prevalence of peripheral enthesopathy and arthropathy in the studied group may explain this result, different from the results obtained in the British population.

Consistent results, on the association of DRB1 alleles with AS, have been difficult to ascertain in different ethnic groups. A Finnish report proposed that, in this specific population, the HLA-DRB1 alleles do not seem to play a strong role in AS susceptibility , but may influence the age of symptom onset (Jaakkola, et al., 2006). The results, in this casecontrol study, are limited due to the sample size. Still, a strong association of DRB1*08, both independent and as part of a HLA-B27 haplotype, was suggested. HLA-DRB1*08 had been already reported in juvenile-AS B27-positive individuals, in Norwegian population (Ploski, et al., 1995). Two haplotypes were identified in a British case-control study: B²7positive /DRB1*07positive and B*27negative /DRB1*03positive (Sims, A M, et al., 2007). The frequency of HLA-DRB1*15 was found to be increased, in Tunisian AS patients, but this allele was in LD with B27 (Mahfoudh, et al., 2011). Within the same population, a casecontrol study reported a significant increase in HLA-DRB1*11 frequency among patients. It was also found a possible protective effect of HLA-DRB1*13 (Kchir, et al., 2010).

Recently, in a Spanish/Portuguese cohort, it was reported the association between HLADPA1 and HLA-DPB1 alleles and AS (Díaz-Peña, et al., 2011). The study was focused on these two MHC genes that lay on a region unrelated to B27. Both AS patients and controls were HLA-B27 positive. This way it was possible to achieve results from an HLA-B27 neutral point of view. The data showed significant results between AS and DPA1*01:03, 
DPA1*02:01, DPB1*13:01. It was also found an association between two haplotypes and AS, namely: DPA1*02:01-DPB1*11:01:01 and DPA1*02:01-DPB1*13:01. This was the first study to show an association between this region of MHC and susceptibility to AS. Consequently, further replicates are needed to confirm these results.

\begin{tabular}{|c|c|c|c|}
\hline \multicolumn{4}{|c|}{ Genes with consistent association to ankylosing spondylitis } \\
\hline Gene & Locus & Mechanism & Population origin \\
\hline HLA-B27 & $6 \mathrm{p} 21.3$ & $\begin{array}{l}\text { Presents endogenously processed antigens } \\
\text { to } \mathrm{T} \text { cells }\end{array}$ & $\begin{array}{l}\text { Caucasian and non- } \\
\text { Caucasian }\end{array}$ \\
\hline $\begin{array}{l}\text { HLA-B60 } \\
\left({ }^{*} 4001\right)\end{array}$ & $6 \mathrm{p} 21.3$ & $\begin{array}{l}\text { Presents endogenously processed antigens } \\
\text { to } \mathrm{T} \text { cells }\end{array}$ & $\begin{array}{l}\text { Caucasian and non- } \\
\text { Caucasian }\end{array}$ \\
\hline $\begin{array}{l}\text { ERAP1/ART } \\
\text { S1 }\end{array}$ & $5 q 15$ & $\begin{array}{l}\text { Peptide trimming prior to HLA Class I } \\
\text { presentation and cleaving cytokine } \\
\text { receptors from cell surface }\end{array}$ & $\begin{array}{l}\text { Caucasian and Han- } \\
\text { Chinese }\end{array}$ \\
\hline IL23R & $1 \mathrm{p} 31.3$ & $\begin{array}{l}\text { Differentiation of naive CD4 T cells into } \\
\text { helper Th17 T cells }\end{array}$ & $\begin{array}{l}\text { Caucasian and Han- } \\
\text { Chinese }\end{array}$ \\
\hline KIF21B & $1 \mathrm{p} 32$ & $\begin{array}{l}\text { Transport of essential cellular components } \\
\text { along axonal and dendritic microtubules }\end{array}$ & Caucasian \\
\hline - & 2p15 & Unknown & Caucasian \\
\hline- & $21 \mathrm{q} 22$ & Unknown & Caucasian \\
\hline \multicolumn{4}{|c|}{ Genes with suggestive association to ankylosing spondylitis } \\
\hline Gene & Locus & Mechanism & Population origin \\
\hline IL1R2 & 2q11 & Interference in the binding of IL-1 to IL-1R1 & $\begin{array}{l}\text { Caucasian and non- } \\
\text { Caucasian }\end{array}$ \\
\hline IL12B & $5 q 31$ & $\begin{array}{l}\text { Heterodimerises with the IL23 p19 subunit, } \\
\text { to form IL23R }\end{array}$ & Caucasian \\
\hline CYP2D6 & $\begin{array}{l}22 q 13 . \\
1\end{array}$ & Metabolism of xenobiotics & $\begin{array}{l}\text { Caucasian (North } \\
\text { European) }\end{array}$ \\
\hline TNFR1 & $12 \mathrm{p} 13$ & Influence on TNF signaling & Caucasian \\
\hline TNFSF15 & $9 q 32$ & $\begin{array}{l}\text { Differentiation of naive CD } 4 \mathrm{~T} \text { cells into } \\
\text { helper Th17 T cells }\end{array}$ & Caucasian \\
\hline ANTRX2 & $4 q 21$ & $\begin{array}{l}\text { Binds to collagen IV and laminin, possibly } \\
\text { involved in extracellular matrix adhesion }\end{array}$ & $\begin{array}{l}\text { Caucasian and Han- } \\
\text { Chinese }\end{array}$ \\
\hline \multicolumn{4}{|l|}{ Other genes } \\
\hline Gene & Locus & Mechanism & Population origin \\
\hline ANKH & $5 p 15.2$ & $\begin{array}{l}\text { Exports inorganic pyrophosphate from } \\
\text { intracellular to extracellular compartments. } \\
\text { Regulates tissue calcification }\end{array}$ & $\begin{array}{l}\text { Caucasian and Japanese } \\
\text { (small cohorts) }\end{array}$ \\
\hline KIR & $\begin{array}{l}19 \mathrm{q} 13 . \\
4\end{array}$ & $\begin{array}{l}\text { Regulates activation of NK cells via } \\
\text { recognition of HLA class I molecules on } \\
\text { target cells }\end{array}$ & $\begin{array}{l}\text { Caucasian and Han- } \\
\text { Chinese (small cohorts) }\end{array}$ \\
\hline TGFB1 & $19 q 13$ & $\begin{array}{l}\text { Mediates inflammation, fibrosis and bone } \\
\text { remodelling }\end{array}$ & Caucasian (one study) \\
\hline TNAP & $1 \mathrm{p} 36.1$ & $\begin{array}{l}\text { Receptor on monocytes important in } \\
\text { apoptosis, binds lipopolysaccharide }\end{array}$ & Caucasian (one study) \\
\hline CD14 & $5 q 31.1$ & $\begin{array}{l}\text { A phosphoethanolamine and pyridoxal- } 5^{\prime}- \\
\text { PO4 actingectophosphatase. Degrades PPi }\end{array}$ & $\begin{array}{l}\text { Caucasian (Finnish small } \\
\text { cohort) }\end{array}$ \\
\hline
\end{tabular}

Table 1. Genes associated to AS - adapted from (Brown, 2010; Reveille, J D, 2011). 


\subsection{Non-major histocompatibility complex genes}

\subsubsection{ERAP1/ARTS1}

The association between Endoplasmic Reticulum Aminopeptidase 1 (ERAP1) and AS was first reported in Caucasians, together with IL23R (Consortium WTCCC/TASC, 2007). Contrarily to the IL23R, the association of ERAP1 was later confirmed in other ethnic groups (Chen, R., et al., 2011). ERAP1 molecules are encoded by the oxytocinase subfamily, a group of three genes located on the chromosome 5 (5q15) (Brionez \& Reveille, 2008), and are located in the endoplasmatic reticulum lumen (Saric, et al., 2002).

The involvement between ERAP1 and MHC class I presentation was the first suggested and confirmed function attributed to this aminopeptidase (Saric, et al., 2002; Saveanu, et al., 2005). ERAP1 is MHC class I dependent and play a major role on peptide trimming, processing it to optimal length, for presentation at cell surface (Saveanu, et al., 2005), having an important connection to the immune recognition mechanism related to CD8+ $\mathrm{T}$ cells. However, it is proposed that the referred importance varies depending both on the antigen and the cell physiological state. It was shown that, contrarily to other peptidases, ERAP1 cleaves $\mathrm{NH}_{2}$-terminal from peptides longer than ten residues and, consequently, is able to produce peptides containing eight to nine residues from longer precursors (York, et al., 2002). This fact support the relation with MHC class I molecules and indicates a possible coevolution between these 2 groups of molecules, since MHC class I require eight to nine residues peptides for a stable binding (York, et al., 2002). Due to the involvement between ERAP1 and MHC class I, these molecules and their trimming mechanisms are consequently involved with HLA-B27, an MHC class I variant (Campbell, et al., 2011). For some years, it was stated that a deeper understanding about ERAP1 function and its relation with B27, at peptide production level, would lead to new insights on the paths that support the well known association between HLA-B27 and AS.. This aspiration was recently fulfilled by the latest GWAS on AS (Consortium TASC/WTCCC2, 2011). It was shown that HLA-B27 positive and negative AS cases differ in association with ERAP1. This fact provided the first reliable replicated example of a gene-gene interaction in AS, indicating that the mechanism by which HLA-B27 induces AS involves aberrant presentation or handling of peptides (Consortium TASC/WTCCC2, 2011).

The cleavage of cytokine cell surface receptors is another function documented to ERAP1. The shedding of IL-1R2, promoted by ERAP1, was already reported in coimmunoprecipitation experiments (Cui, et al., 2003a). Through the use of cell lines, it was possible to achieve a correspondence between ERAP1 overexpression, the increase of IL1-R2 shedding and the decrease of membrane-associated IL1-R2. It was also found that ERAP1 is necessary for constitutive IL1-R2 shedding, as basal IL1-R2 shedding is absent from ERAP1 knockout cell lines (Cui, et al., 2003a). The exact same correlations were already observed in reports regarding TNFR1 (Cui, et al., 2002) and IL6R (Cui, et al., 2003b). These findings were not confirmed when was measured the appearance of those receptors in cell culture supernatants from single-cell suspensions, stimulated with plate-bound anti-CD3 (Clone 145-2C11) and phorbol 12-myristate 13-acetate (PMA), prepared from mouse spleens. No difference in the levels of these receptors was observed over time, indicating that ERAP1 does not have a major influence on cytokine receptor trimming, at least in mice (Consortium TASC/WTCCC2, 2011). Further tests may contribute to the clarification of the mechanisms underlying the association between ERAP1 and AS. An abnormal increase or decrease in the 
amount of those cytokine cell surface receptors is an expected outcome of ERAP1 malfunctioning. Thus, the susceptibility to AS can emerge as a consequence of proinflammatory effects related to that amount variation (Chen, R., et al., 2011; Consortium WTCCC/TASC, 2007).

Since the confirmed association between ERAP1 and AS reported in 2007(Consortium WTCCC/TASC, 2007), some replications occurred in studies involving Caucasian (Consortium TASC, 2010; Harvey, et al., 2009a; Maksymowych, W. P., et al., 2009; Pazar, et al., 2010; Pimentel-Santos, et al., 2009; Tsui, F. W., et al., 2010) and Han Chinese cohorts (Bang, et al., 2011; Choi, et al., 2010; Davidson, et al., 2009). The Wellcome Trust CaseControl consortium and Australo-Anglo-American Spondyloarthritis Consortium first described the association of five ERAP1 single nucleotide polymorphisms (SNPs) and AS (Consortium WTCCC/TASC, 2007), namely rs27044, rs17482078, rs10050860, rs30187 and rs2287987. Two of these SNPs, rs27044 and rs30187, gathered more consistent results in the subsequent reports and were the only markers that showed significant association both in Caucasian and in Han Chinese groups (Choi, et al., 2010; Harvey, et al., 2009a; Maksymowych, W. P., et al., 2009; Pazar, et al., 2010; Pimentel-Santos, et al., 2009). The significant relation between rs27044 and AS was not confirmed in Canadian, contrarily to all other replicates involving this SNP and Caucasian groups. However, in that same cohort, it was found an ERAP1 haplotype, containing rs27044, which increased the risk of AS: rs2044/10060860/30187-CCT (Maksymowych, W. P., et al., 2009). The other mentioned SNP, rs30187, did not show a significant association with AS in a group from Hungary (Pazar, et al., 2010). However, this result has low impact compared to the other studies performed, since the obtained P-value was 0.051 and the sample was the smallest of all the mentioned cohorts. The rs30187 (Arg528Lys) is the only coding marker within a SNP block recently identified in GWAS (Consortium TASC, 2010). This variant showed a really strong significant association in another GWAS using a large Caucasian cohort $\left(\mathrm{P}=1.8 \times 10^{-27}\right)$ (Consortium TASC/WTCCC2, 2011). It was shown that this marker originates a significant decrease in aminopeptidase activity toward a synthetic peptide substrate. Moreover, modeling of ERAP1 protein points out to the presence of Arg528 at the mouth of the putative enzyme substrate pocket. This location can explain the reduction of the aminopeptidase activity of the molecules that contain this variation (Goto, et al., 2008; Kochan, et al., 2011). These results and reported data from family based studies (Tsui, F. W., et al., 2010) support this SNP as one of the ERAP1 variants with strongest association to AS.

The remaining SNPs found by The Australo-Anglo-American Spondyloarthritis Consortium (TASC) \& Wellcome Trust Case Control Consortium (WTCCC) didn't show consistent results in other sudies. The first published study, after WTCCC/TASC report, was not able to identify a significant association between rs2287987, rs17482078 or rs10050860 and AS in a Portuguese group (Pimentel-Santos, et al., 2009). The same result was obtained in a Han Chinese group (Choi, et al., 2010). The rs17482078 significant association (Consortium WTCCC/TASC, 2007) was not confirmed also in already mentioned Hungary group (Pazar, et al., 2010). Other replications using Caucasian cohorts were able to find significant associations between rs2287987, rs10050860 and AS (Harvey, et al., 2009a; Maksymowych, W. P., et al., 2009; Pazar, et al., 2010). Recently, a meta-analysis that included all the ERAP1 association studies, confirmed the presence of a significant association between the SNPs reported by the Consortium WTCCC/TASC and AS (Chen, R., et al., 2011). Moreover, it was proposed that the contradictory results, obtained in some replications, can be an effect of 
the clinical heterogeneity, ethnic differences or real genetic heterogeneity, the small sample size of the studies or their low statistical power (Chen, R., et al., 2011).

The Consortium TASC included ERAP1 in the first GWAS for AS, already mentioned above. This work included a large Caucasian cohort and narrowed down the ERAP1 region, associated to AS, to a block of SNPs lying in a 4.6-kb region between rs27529 (exon 9) and rs469758 (intron 12) (Consortium TASC, 2010). The identified region showed an association 50 times more significant than any other imputed SNP $\left(\mathrm{P}<10^{-11}\right)$. The overall results showed strong association of two SNPs that were not reported in previous Caucasian studies, rs27037 and rs27434. The data obtained in a Han Chinese group, published before TASC GWAS showed moderate association of $\operatorname{rs} 27037(\mathrm{P}=0.012)$ and did not observe the association of rs27434 ( $\mathrm{P}=0.14)$ (Davidson, et al., 2009). The same result was attained by the recent meta-analysis already cited (Chen, R., et al., 2011). On the other hand, the strong association of both markers was recently confirmed in a Korean group (Bang, et al., 2011). Once more, together with ethnic differences, the results seem to be influenced by the effect genetic heterogeneity.

The data concerning ERAP1 haplotypes is limited; however the available results seem to point out to some haplotypes that influence the risk of disease. The rs2044/10060860/30187CCT haplotypes increased the risk of disease in 3 Canadian case-control cohorts. This haplotype is in one of the two strongly significant haplotypes, out of four, that were identified among Koreans: rs27044/rs17482078/rs10050860/rs30187-GCCT and rs27044/ rs17482078/rs10050860/rs30187-CCCC (Choi, et al., 2010). All these four SNPs formed an LD block with almost complete LD $\left(95<\mathrm{D}^{\prime}<100\right)$ (Choi, et al., 2010; Tsui, F. W., et al., 2010). The Canadian study reported a protection effect of rs30187/26618/26653-CTG ERAP1 haplotype (Maksymowych, W. P., et al., 2009). A family-based study was not able to support the significant association of rs2044/10060860/30187 haplotype, but here a relatively small sample was used (Tsui, F. W., et al., 2010). Moreover, the results are probably an underestimate since some of the studied families had more than two affected individuals (35 ) and the method used by the authors for power estimation took into account only two affected family members. Despite this lack of confirmation, it was possible to identify significant association between rs27044/rs2549782-GT and rs30187/rs2549782-TT haplotypes and AS. In addition, a novel finding showing that rs27044/rs30187/rs2549782GTT haplotype in the ERAP1-ERAP2 loci was significantly associated with disease susceptibility for both models used (Tsui, F. W., et al., 2010).

\subsubsection{IL23R}

The association between Interleukin 23 receptor (IL23R) and AS has been confirmed throughout the last few years, since the first association evidence, reported by the WTCCC/TASC study (Consortium WTCCC/TASC, 2007).

IL23R is a member of heamopoietin receptor family, which binds to IL-23 mediating its activity. This hemopoietic cytokine receptor is encoded on chromosome 1 (1p31.3), by a gene located $150 \mathrm{~kb}$ far from the gene for IL-12R $\beta 2$ (Parham, C., et al., 2002). IL23 is a heterodimeric cytokine consisting of two subunits: p40, which is shared with IL-12, and p19 (Oppmann, et al., 2000). IL-23 has also other biological connections with IL-12; activated human PHA blast T cells, when induced by IL-23, register a better proliferation and IFN- $\gamma$ 
production, like when they are induced by IL-12. However, IFN- $\gamma$ levels produced in cells stimulated by IL-23 are always lower than those induced by IL-12. In the presence of IL-23, naive $\mathrm{T}$ cells only increase the producing of IFN- $\gamma$ after a long stimulation. In contrast, memory T cells - human and mouse - and NKL cells register a strong response to IL-23, enhancing IFN- $\gamma$ production (Oppmann, et al., 2000; Parham, C., et al., 2002). The cells response to either IL-12 or IL-23 is linked to the level of IL-12R $\beta 2$ or IL23R expression, respectively (Parham, C., et al., 2002).

IL23R is one of the two subunits of IL-23 receptor complex, present on IL-23-responsive cells. The other component is IL-12R $\beta 1$ and is shared with IL-12 receptor. Despite the similarities in the structure of both receptors, in the presence of IL23R subunit, cells respond to IL-23 and not to IL-12 (Parham, C., et al., 2002). Human IL23R is expressed on T cells, Natural-Killer (NK) cells, monocytes and DCs, all cells that are able to respond to IL-23 (Belladonna, et al., 2002; Parham, C., et al., 2002). The IL23R has an important role in CD4 Tcell differentiation, since it encodes a critical cytokine receptor in the TH17 lymphocyte subset. The TH17 cells were already identified as mediators of inflammatory process in several models of autoimmunity (Cua, et al., 2003; Murphy, et al., 2003). Furthermore, they are considered as a distinct subset of T-cells, expressing high levels of IL-17 in response to stimulation (Park, et al., 2005) and are associated to tissue damage in brain, joints, heart, lungs and intestines (Steinman, 2007). Genetic variants of IL23R have also been related with susceptibility to several autoimmune diseases, namely inflammatory bowel disease (IBD) (Duerr, et al., 2006), psoriasis (Cargill, et al., 2007), multiple sclerosis (Nunez, et al., 2008) and AS (Consortium WTCCC/TASC, 2007). A significant association between $I L-12 R \beta 1$ and AS (rs6556416; $\mathrm{P}=1.9 \times 10^{-8}$ ), which encodes one of IL23R and IL-12R subunits, was reported recently by the Consortium WTCCC2/TASC (Consortium TASC/WTCCC2, 2011).

The Consortium WTCCC/TASC reported the strong association $(\mathrm{p} \leq 0.008)$ of eight IL23R SNPs and AS, rs11209026, rs1004819, rs10489629, rs11465804, rs1343151, rs10889677, rs11209032, rs1495965 (Consortium WTCCC/TASC, 2007). The strongest association reported was with SNP rs11209032 $\left(\mathrm{p}=7.5 \times 10^{-9}\right)$ with an attributable risk of $9 \%$. The power of this association was consistent, even when only AS cases, without IBD. were considered. It was stated that this fact could be the result of a primary association with AS, and thus, not related to the presence of IBD (Consortium WTCCC/TASC, 2007). These findings were replicated in several studies; however, there are some conflicting results, especially when analyzing different ethnic groups. A recent GWAS used the same British cohort, and included a new sample composed by Australian, British and North American individuals. In this large cohort a strong AS association to SNP rs11209026 $\left(p=2.3 \times 10^{-9}\right)$ was identified (Consortium TASC, 2010). This association was soon after confirmed by the most recent GWAS reported by the TASC/WTCCC2 consortia (Consortium TASC/WTCCC2, 2011).

Closely after the WTCCC/TASC report, a Canadian and a Spanish study were able to replicate some of the already studied IL23R SNPs (Rahman, et al., 2008; Rueda, et al., 2008). The Canadian study encompassed 3 cohorts and tested the association of 10 IL23R SNPs: rs7517847 and rs2201841, plus the SNPs reported by WTCCC/TASC. Significant associations, to the SNPs rs1004819 and rs11209032, were also found in a Portuguese cohort (Pimentel-Santos, et al., 2009), and in the Alberta population, respectively. The SNPs rs11209026 (Arg381Gln) and rs11465804 revealed association with AS in both Newfoundland and Toronto groups. The last SNP, revealed the strongest protective effect in 
these two cohorts and it was in LD with rs11209026. The Toronto population also registered significant differences in rs7517847 (Rahman, et al., 2008).

In the Spanish group, the obtained results were able to corroborate the previous findings for rs1343151, rs11209026 and rs10889677. In this cohort the SNPs revealed a protective effect. The association of the remaining SNPs, reported by the consortium WTCCC/TASC, was not confirmed. The involvement of rs11465804 was not tested, on the other hand, like in the Canadian study, it was included the SNP rs7517847 but no significant result was found for this variation (Rueda, et al., 2008). In this population, rs1343151 showed a stronger association $\left(\mathrm{P}=2 \times 10^{-4}\right)$. This findings, together with the Canadian study results previously mentioned (Rahman, et al., 2008), points out to a protection effect of the Arg381Gln nonsynonymous polymorphism. The changing of Arg381 for Gln381 may modify the interaction between IL23R and its associated JAK2 kinase (Parham, C., et al., 2002). The authors proposed that this variation can interfere with the IL23R transducing pathway leading to a reduction in cellular response to IL-23, explaining this way the protective effect of Gln381 allele (Rahman, et al., 2008; Rueda, et al., 2008).

A Portuguese study was not able to confirm all this findings (Pimentel-Santos, et al., 2009). The modest power of the study can explain the results. However, as it was already mentioned, a significant association was found for rs1004819. The minor allele frequencies observed in this study were similar to those reported in British and North Americans. Furthermore, this association had a similar magnitude of effect to the one already reported in those populations. The attributable risk for rs1004819 in Portuguese cohort, is very similar to the one reported to rs11209032 in the British/North American populations (Consortium WTCCC/TASC, 2007; Pimentel-Santos, et al., 2009). Using the obtained results, the authors performed a meta-analysis study combining the Portuguese data and the previously published Spanish data (Rueda, et al., 2008). Considering fixed effects, three IL23R SNPs revealed significant association rs1004819, rs1343151 and rs11209026. When random effects were considered for the analysis of combined data, only rs1004819 was found to have significant association, confirming the result found when only the Portuguese cohort was analyzed (Pimentel-Santos, et al., 2009).

The results obtained for rs1004819 in the Iberian population were confirmed in the Hungarian population (Pimentel-Santos, et al., 2009; Safrany, et al., 2009). This study was performed with a small number of samples; even so, it was possible to register some significant associations. It was shown that the presence of rs1004819 allele A increases the risk for AS in more than two-fold. The same increase was registered when rs10889677 was considered. Significant results were also found for rs11209026. Besides the SNPs reported in the initial association study (Consortium WTCCC/TASC, 2007), the authors also included rs11805303, which was significantly increased in patients with AS. The minor allele of this SNP conferred a 1.6-fold risk for the development of the disease in the studied cohort (Safrany, et al., 2009). The presence of rs11209026 revealed no significant difference between patients and controls when only HLA-B27 positive AS patients were included in the statistical analysis. Thus, the association found for rs11805303 and rs10889677 had a marginal significance when comparing controls with the HLA-B27 patients. Nevertheless, all the other variants kept their significant results, showing that HLA-B27 status has no real effect on the effect of IL23R (Safrany, et al., 2009). 
A meta-analysis, reported at the same year, included the first United Kingdom and United States cohort published (Consortium WTCCC/TASC, 2007), the Canadian groups (Alberta, Newfoundland and Toronto) (Rahman, et al., 2008), the Spanish results (Rueda, et al., 2008) plus a new British group (Karaderi, et al., 2009). Just like stated by WTCCC/TASC, the results of this study confirmed the association between AS and all the eight IL23R SPNs analyzed. Once more, the strongest associations were seen with rs11209026 ( $<<10-10)$ and rs11209032 ( $\mathrm{P}=4.06 \times 10-9)$ (Karaderi, et al., 2009). The last variant had the same order of magnitude reported by the WTCCC/TASC study (Consortium WTCCC/TASC, 2007). This meta-analysis confirmed the connection of IL23R and AS susceptibility in Caucasians.

The first replication, performed in a group with a different ethnic background, did not confirm the association of IL23R and AS in Han Chinese (Davidson, et al., 2009; Sung, et al., 2009). These findings may indicate a difference in the mechanism of disease pathogenesis between Caucasian and Han Chinese populations. The authors proposed that the development of AS developing Chinese can result from a mechanism independent of any IL23R polymorphism. This difference could be the result of the association with a different gene also involved in the IL23R signaling pathway (Davidson, et al., 2009). Other explanation to this lack of association is the absence of polymorphism of rs11209026 in Chinese. This variant, as described above, is pointed out as one of the causative SNP for disease susceptibility in Europeans. However, recent published data reported association of some IL23R SNPs and AS in a Chinese cohort (Wang, et al., 2010). In this group it was found, for the first time, a significant association between rs6677188, located in the intergenic region, and AS susceptibility. The previously reported association of rs11209032 in Caucasians was confirmed also in Chinese. Through the analysis of paiwised LD, it was found that rs11209032 and rs6677188 were in strong LD, in this population (Wang, et al., 2010).

\subsubsection{KIF21B}

The gene KIF21B (Kinesin Family 21B) is one of the most recent loci with confirmed association to AS. This gene belongs to a family of kinesin motor proteins that are involved in the transport of essential components along axonal and denditric microtubules by neurons. A GWS found strong association for $\operatorname{rs} 11584383$ (1q32) $\left(\mathrm{P}=1.6 \times 10^{-10}\right)$, a SNP located downstream of and flanked by KIF21B (Danoy, et al., 2010). This strong association was corroborated by WTCCC2/TASC. Here, the SNP rs2297909 showed the strongest association with AS ( $\left.\mathrm{P}=5.2 \times 10^{-12}\right)$ (Consortium TASC/WTCCC2, 2011). Both studies were conducted with Caucasian cohorts. Despite the confirmed association in this ethnic group, further replications in other ethnic groups are mandatory.

\subsection{Intergenic regions - 2p15 and $21 q 22$}

It has been estimated that approximately $25 \%$ of the human genome consists of gene deserts defined as generally long regions, ranging from a few base pairs to $5.1 \mathrm{Mb}$, containing no protein-coding sequences and with no obvious biological functions (Venter, et al., 2001). Ovcharenko et al. found that conservation clearly separates two distinct categories of gene deserts: weakly conserved variable gene deserts and more conserved stable gene deserts (Ovcharenko, et al., 2005). Moreover, it has already been shown that some human gene deserts harbour distant regulatory elements that are deeply conserved in vertebrate species 
(Kimura-Yoshida, et al., 2004; Nobrega, et al., 2003). Several diseases have been associated with these particular areas of the genome; possible explanations to elucidate the mechanisms underlying these associations include: 1) epigenetic effects, 2) unknown protein-coding transcripts, 3) effects of long range transcriptional regulatory elements and 4) effects of non-coding RNA that can influence gene expression (Brown, 2010).

A GWAS has recently identified the new association of two narrow intergenic regions, in chromosomes $2(23 \mathrm{~kb})$ and $21(11 \mathrm{~kb})$, with AS. This study found, in each intergenic region, a block of SNPs in tight linkage disequilibrium encompassing areas that likely contain the causative variants responsible for the observed association (Consortium TASC, 2010). Another GWAS recent study replicated this association and has shown that SNPs at these intergenic regions are independent of the HLA-B27 presence, since it is associated with AS in both HLA-B27 positive and HLA-B27-negative patients (Consortium TASC/WTCCC2, 2011).

The intergenic area 2 p15 does not contain any known gene and, until now, this has been the only association to a disease (Reveille, J. D., et al., 2010). The association to AS was already been replicated in a small study in the Spanish population. The SNP rs10865331 was typed in four hundred and fifty six AS patients and 300 healthy donors, and the result was a significant association with AS, while no association was found for rs2242944, in 21q22 (Consortium TASC/WTCCC2, 2011).

The other intergenic AS associated area, at chromosome 21q22, has already been associated with a closely related condition: paediatric-onset inflammatory bowel disease (IBD) (Kugathasan, et al., 2008). Remarkably, the most strongly IBD associated SNP is in strong linkage disequilibrium with the strongest ankylosing spondylitis-associated marker (Consortium TASC, 2010). The nearest gene, to this region, lies at $82 \mathrm{~kb}$ distance (PSMG1) and encodes for a proteasome assembly chaperone 1 (Consortium TASC, 2010). According to the authors' opinion, it is unlikely that PSMG1 is a candidate gene directly involved in AS susceptibility since 1) this gene was not differentially expressed in peripheral blood mononuclear cells from cases with active AS when compared with healthy controls, 2) the large distance to the associated locus and 3) the lack of evidence of a relevant biological function.

It is suggested that both these regions at chromosomes 2 p15 and 21q22, contain long mRNA-like noncoding RNA species or until now unreported protein-coding genes that may be involved in AS susceptibility (Consortium TASC, 2010).

\section{Genes suggestively associated with ankylosing spondylitis}

\subsection{IL1 gene cluster}

Interleukin-1 (IL-1) and its related family members are key cytokines in autoimmune and inflammatory diseases produced by monocytes, macrophages, and dendritic cells. They are cell surface associated proteins and stimulate the expression of several genes, affecting both the innate and acquired immune systems (Dinarello, 2002). IL1-F1, IL1-F2, IL1-F3, and IL1F4 are the primary members of the family. IL1-F1, IL1-F2, and IL1-F4 are each agonist while IL1-F3 is a receptor antagonist for IL1-F1, IL1-F2 (Dinarello, 2002). When the antagonist occupies the receptor, there is no signal transduction as the IL1-F1 and IL1-F2 can not bind 
the specific receptor. All IL-1 genes are located on the long arm of chromosome 2 except IL18 and IL-18 binding protein (IL-18BP) which are located on chromosome 11. Some member of the family as IL1-F5, IL1-F7, and IL1-F9 are gene duplications and they are very closely related to IL1-F3 (Mulero, et al., 1999). The exact function of these genes is still unclear.

The IL-1 receptor family is composed of nine genes. IL1-R1, IL1-R2, and IL1-R3 are the bona fide receptors while the rest are called 'orphan' receptors as they lack of specific ligand Anyway, some gene regulation studies found non-specific proteins binding to orphan receptors (Gayle, et al., 1996; Moritz, et al., 1998; Parnet, et al., 1996; Torigoe, et al., 1997). The most studied receptor of the family is the IL1-R2 (Symons, et al., 1991). IL1-R2 receptor acts as a decoy receptor. It has a high affinity for IL1-F1 and IL1-F2 and a lower affinity for IL1-F3. After the cleavage from cell membrane by ERAP1, IL1-R2 binds IL1-F1 interfering with IL1-F1 / IL1-R1 binding. Its extracellular domain is homologue of the IL1-R1 but the intracellular domain is shorter and lacks of TIR domain (Dunne \& O'Neill, 2003). Therefore when activated, IL-R2 is unable to initiate any biological response.

Positive association between AS and IL1-F3 gene was observed in earlier studies with high frequency of the allele 2 of IL1-F3 variable nucleotide tandem repeat (VNTR) in AS patients (Dunne \& O'Neill, 2003; van der Paardt, et al., 2002). The result was further confirmed through a recent study on meta-analysis of $I L-1$ gene cluster ( $\mathrm{Wu} \& \mathrm{Gu}, 2007)$. A significant association between two IL1-F3 intronic SNPs and AS susceptibility was also found at position 30735 and 30017 in exon 6 (Chou, et al., 2006; Maksymowych, W. P., et al., 2003). A significant difference of the distribution of haplotypes was found between the AS affected and healthy individuals. On the contrary, in earlier studies no association between AS and IL1-F3 gene was found (Djouadi, et al., 2001; Jin, et al., 2004; Kim, et al., 2005; Maksymowych, W. P., et al., 2006; Timms, A. E., et al., 2004). These findings were also observed in the genome scan carried out by North American Spondylitis Consortium (NASC) (Jin, et al., 2004). In this work, six exons and introns in 102 white patients and 50 controls were sequenced and no association was revealed. Moreover, other genes in the IL-1 cluster have been analyzed. In nine IL-1 genes, were identified SNPs showing significant association with AS (Timms, A. E., et al., 2004). Maksymowych et al. identified 14 SNPs with high association in at least one cohort (Maksymowych, W. P., et al., 2006). The most significant cohorts were in IL1-F1 and IL1-F2. In a more recent meta-analysis nine SNPs were analyzed and a strong association was observed in three IL1-F1 loci (Sims, A. M., et al., 2008).

\subsection{ANTXR2}

The ANTXR2 gene encodes for a transmembrane protein which serves as receptor of anthrax toxin (Thomas \& Brown, 2010). Also known as capillary morphogenesis protein 2 (CMP2), the receptor recognises and binds the toxin, allowing anthrax to attach the cells and triggering the disease process. It is widely expressed in human tissue including in the hearth, lung, liver, placenta, small intestine, kidney, colon, and skeletal muscles. Expressed primarily in macrofages, it is involved in capillary formation and extracellular matrix adhesion (Reveille, J D, 2011). Recessive mutations in ANTXR2 gene are associated to two autosomal diseases, infantile systemic hyalinosis (ISH; MIM\#237490) and juvenile hyaline fibromatosis (JHF; MIM\#228600) (Consortium TASC, 2010). 
In a recent study on unrelated cases of AS among Australian, British, and North American individuals of European descent, carried out by TASC, a strong association between polymorphism in ANTXR2 gene and AS was found (Consortium TASC, 2010). In the same year, investigating on AS susceptibility in 1164 Korean patients, Bang et al. confirmed the differentially expression of ANTXR2 gene in AS (Bang, et al., 2011). In contrast no association was observed between ANTXR2 polymorphism and AS in Chinese Han population (Chen, C., et al., 2010). With these divergent results, it is still not clear if ANTXR2 influences the disease and how it is involved in the pathogenesis. IT has been suggested that it can act at intestinal permeability level given its function in epithelial barriers (Thomas \& Brown, 2010). The previous results reported by TASC were confirmed by another GWS that also found significant association in the ANTXR2 area $\left(\mathrm{P}=9.4 \times 10^{-8}\right)$ (Consortium TASC/WTCCC2, 2011).

\subsection{TNFSF15}

The Tumor Necrosis Factor Ligand Superfamily, Member 15 (TNFSF15, also known as TNF superfamily ligand A, TL1A or vascular endothelial cell growth inhibitor, VEGI) is a TNFlike factor encoded on the chromosome 9 (9q32). The molecules are primarily expressed in endothelial cells and its expression is highly inducible by TNF and IL-1A (Migone, et al., 2002; Yue, et al., 1999). Strong evidences point to a significant genetic association between the TNFSF15 gene and inflammatory bowel disease (IBD). The data was obtained in populations from different ethnic backgrounds, namely Caucasians and Japanese (Yamazaki, et al., 2005). A WGAS for AS in Caucasians reported the existence of linkage on chromosome 9q (Laval, et al., 2001). This was supported by another WGS for spondyloarthropathies (SpA) susceptibility genes, performed on multiplex families, which detected a significant linkage on chromosome 9q31-34, including the TNFSF15 encoding region (Miceli-Richard, et al., 2004). However, this region was not identified in a recent GWAS (Consortium TASC, 2010).

Recently, comprehensive linkage and association analyses reported, for the first time, an association between several SNPs near the TNFSF15 gene and SpA (Zinovieva, et al., 2009). The authors aimed to narrow down the susceptibility region for SpA found on the first GWAS reported by the same authors (Miceli-Richard, et al., 2004). The obtained data showed two areas of statistically significance linkage. The highest linkage peak was located on the marker D9S1824 at $115.9 \mathrm{Mb}$ from the p-telomere. The second significant area was located near D9S1682, a suggestive linkage peak reported in WGS for AS (Laval, et al., 2001). This finding supports the validity of linkage between this region and SpA.

The analysis of combined data from family-based and case/control studies showed a strong association $(\mathrm{P}<0.001)$ of 7 SNPs: rs4979459, rs7849556, rs10817669, rs10759734, rs6478105, rs10982396 and rs10733612 (Zinovieva, et al., 2009). The SNP rs4246905 also showed a significant result but with a lower level $(\mathrm{P}=0.01)$. Six of this SNPs compose a $40.3 \mathrm{~Kb}$ block with a high degree of LD, found in the same study. This LD block included two genes, LOC389786 and TNFSF15 (Zinovieva, et al., 2009). The rs6478105 revealed to be the strongest individual associated SNP in the overall dataset $\left(\mathrm{P}=3 \times 10^{-5}\right)$. The SNPs associated with Crohn's disease were not associated with SpA in this study. Haplotypes research also confirmed this tendency and showed that haplotypes composed of markers of this block were significantly associated with the disease. Two significant individual haplotypes were 
found in family-based study: rs7849556/ rs10817669/ rs10759734/ rs6478105/ rs10982396/ rs10733612 - AAAACC and rs7849556/ rs10817669/ rs10759734/ rs6478105/ rs10982396/ rs10733612 - CGGACT. The pooled case/control investigation revealed a significant strong association of the individual haplotype rs7849556/ rs10817669/ rs10759734/ rs6478105/ rs10982396/ rs10733612 - CGGGGT (Zinovieva, et al., 2009).

TNFSF15 is a ligand for the receptors DR3 (death domain receptor 3, also known as TNFRSF25 (tumor necrosis factor receptor super-family, member 25) and TR6/DcR3 (decoy receptor 3, also called TNFRSF6B - tumor necrosis factor receptor super-family, member 6b) (Migone, et al., 2002). The ligand-receptor pairing of TNFSF15-DR3 was already pointed as a regulator of Th17 differentiation and activation (Pappu, et al., 2008; Takedatsu, et al., 2008). An increased level of Th17 cells in AS patients, when compared to healthy controls, was already reported (Jandus, et al., 2008). Therefore, targeting the TNFSF15-DR3 pathway could provide new insights in the role of TNFS15 in AS development.

\subsection{TNFRSF1A and TRADD}

The TNFRSF1A (Tumor necrosis factor receptor superfamily member 1A, also known as tumor necrosis factor receptor 1 - TNFR1) association with AS was reported by the TASC GWAS. Several TNFRSF1A SNPs showed moderate levels of association in the discovery set and, among them, rs1800693 showed the strongest association $(\mathrm{P}=6.9 \times 10-5)$ (Consortium TASC, 2010). It was hypothasized that TNF1, encoded by TNFRSF1A, was cleaved by ERAP1. The data suggested that ERAP1 extracellular domain binds to the TNFR1 extracellular domain and acts as an extracellular TNFR1 regulatory protein that would promote TNFR1 shedding (Cui, et al., 2002). However, as already mentioned in ERAP1 section, no correlation between presence of ERAP1 and decrease of TNFR1 levels was observed in cultured cells from mice (Consortium TASC/WTCCC2, 2011).

TNF antagonists are highly effective in suppressing inflammation in AS. Thus, some data obtained from studies with mice showed that mesenchymal cells are common primary targets for TNF in the development of AS, and that selective expression of TNFRSF1A on those cells is enough to cause the complete development of AS, as well as inflammatory polyarthritis and inflammatory bowel disease (IBD) (Armaka, et al., 2008). The determination of the polymorphisms involved on that action would allow a better understanding of the relation between TNFRSF1A gene and AS. TRADD (TNF receptor type 1-associated death domain) is located on chromosome 16q, a region already reported in linkage studies (Laval, et al., 2001). TRADD registered moderate levels of association and lies between the SNPs rs9033 and rs868213, which already showed strong association with AS (Pointon, et al., 2010). This gene is a key component of the TNFR1-signaling cascade and is involved in TLR3, TLR4 and D3 signaling (Chen, N. J., et al., 2008; Chinnaiyan, et al., 1996; Hsu, H., et al., 1995).

Recently it was found an AS associated SNP at chromosome 12p13 between LTBR (lymphotoxin beta receptor) and TNFRSF1A (rs11616188; P = 4.1 × 10-12). The authors also found an association at chromosome 17q21 near TBKBP1 (encoding TBK binding protein 1), a component of the TNFR signaling pathway (rs8070463, $\mathrm{P}=5.3 \times 10-8)$. Here, TRADD also showed suggestive association with AS in this study, namely SNP rs9033 ( $\mathrm{P}=4.9 \times 10-5)$ (Consortium TASC/WTCCC2, 2011). Once more, it is mandatory to continue research at this level to determine the precise mechanism underlying these associations. 


\subsection{CYP2D6}

The cytochrome P450 enzymes are responsible for the majority of oxidative (phase I) drug metabolism (1)(Gonzalez, 1992); they are polymorphic although $5-10 \%$ of Europeans lack this activity (described as poor metabolisers) (Cholerton, et al., 1992). At least 15 allelic variants of CYP2D6, that is inherited as an autosomal recessive trait, can cause poor metaboliser phenotype, but $75 \%$ of these are CYP2D6*4 (Brown, et al., 2000). The CYP2D6 genotype was found to be associated with other chronic inflammatory disease and with cancer (Baer, et al., 1986; Daly, et al., 1994).

Beyeler et al. (Beyeler, et al., 1996) first reported a relationship between this gene and the susceptibility to AS, investigating 54 patients and 662 healthy volunteers. The association was modest between AS and CYP2D6 genotype and the effect was greatest for the CYP2D6B allele.

Brown et al. (Brown, et al., 2000) studied linkage of the CYP2D6 gene and association of the main poor metabolizer genotype in 617 unrelated AS patients, 402 healthy controls, and in 361 families with AS. Significant association was observed between homozygosity for CYP2D6*4 and AS, but heterozygosity for allele 4 was not disease associated, and weak linkage of the CYP2D6 polymorphism and AS was found with a LOD score of 0.9. The authors suggested that dysfunction of the CYP2D6 gene increases the risk of AS, although only contributing a small proportion of the overall risk of the disease.

A more recent Turkish study, investigating 100 unrelated AS patients and 52 healthy controls, found no significant risk of AS development for patients with one or two CYP2D6*4 alleles (Erden, et al., 2009).

In conclusion, the cytochrome P450 gene debrisoquine 4-hydroxilase (CYP2D6), encoded at 22q13.1, may have a moderate support for involvement in susceptibility to AS. The mechanisms for susceptibility are unknown but it is possible that the ubiquitous environmental trigger of AS is a natural toxin and reducing its metabolism could increase susceptibility to disease (Brown, 2006).

\section{Other genes}

\subsection{KIR}

The Killer immunoglobulin-like receptor (KIR) genes are a polymorphic group of genes located on chromosome $19 \mathrm{q} 13.4$, and they span $150 \mathrm{~Kb}$ of the leucocyte receptor complex (LCR) (Hsu, K. C., et al., 2002). They express a family of proteins which are activating and inhibitory receptors expressed on natural killer (NK) cells and on a subset of T cells (CD8+). They have been classified in two types: Activating KIRs (KIR2DS and KIR3DS), which have a short (S) cytoplasmic tail with the capacity to interact with activating adaptor proteins such as DAP12 (Lanier, et al., 1998), and inhibitory KIR (KIR2DL and KIR3DL), which has one or two immunoreceptor tyrosine-based inhibition motifs in their long (L) cytoplasmic tail. Further to the allelic polymorphism, haplotypic variability is also described and according to gene content, haplotypes were divided in two basic groups: Haplotype A contains only one activating KIR gene, 2DS4, whereas Haplotype B contains various combinations of activating KIR genes, KIR2DS1, -2DS2, -2DS3, -2DS5, - 3DS1, and -2DS4, 
exhibiting extreme diversity, resulting in different signaling potentials to NK and $\mathrm{T}$ cells (Hsu, K. C., et al., 2002).

The precise function of some KIRs is controversial but it was demonstrated that mature class I complexes act as ligands for immunomodulatary receptors, and it is known that KIR proteins recognize subsets of HLA-A, $-B$, or $-C$ alleles (Parham, P., 2005). It is possible that KIRs may synergise with HLAs to generate activating or inhibitory compound genotypes that provide different levels of activation and inhibition for NK or T cells, which may be associated with differing susceptibility to or protection against a range of diseases.

A study in Caucasian populations demonstrated genetic evidence for the implication of KIR3DL1 and the activating counterpart, KIR3DS1 in AS (Lopez-Larrea, C., et al., 2006). In this study the inhibitory allele was decreased in AS patients compared with B27-positive healthy controls, whereas KIR3DS1 was increased in AS patients. Another study by the same group in two Asian B27-positive populations (China and Thailand), reported some KIR associations with AS susceptibility (Diaz-Pena, et al., 2008). The authors hypothesized that AS patients could possess more activating KIR genes than the healthy control subjects, which could create a genetic imbalance between inhibitory and activating KIR genes that could have influence on the AS pathogenesis.

Another study genotyped 200 UK AS patients and 405 healthy controls for 14 KIR genes. Additionally, sequence-specific oligonucleotide probes were used to subtype 368 cases with AS and 366 controls for 12 KIR3DL2 alleles. The authors concluded that neither the KIR gene content of particular KIR haplotypes nor KIR3DL2 polymorphisms contribute to AS (Harvey, et al., 2009b).

Two more recent studies, one from China and another one from Spain investigated the association of KIR and AS susceptibility. The Chinese study investigated 115 unrelated HLA-B27-positive AS patients and 119 HLA-B27-positive healthy controls, and concluded that the frequencies of KIR2DL1 and KIR2DL5 were significantly higher in the AS patient group although they did not reach statistical significance. Furthermore, the investigators also concluded that HLA-CW* ${ }^{*} 8$ was present more frequently in AS patients than in healthy B27 controls, raising the possibility that HLA-Cw*08 recognized KIRs through the Asp80, thereby contributing to the immune regulation in AS (Jiao, et al., 2010). In the Spanish study 270 AS patients and 435 healthy HLA-B27-positive controls from Spain were genotyped for KIR3DL1/S1 alleles. The authors found that the KIR3DS1*013 allele frequency was increased in patients with AS, and that the null allele KIR3DL1*004 was a unique inhibitory KIR3DL1 allele that showed a negative association with AS (Diaz-Pena, et al., 2010).

Genome-wide scans have implicated regions on chromosomes $2 \mathrm{q}, 6 \mathrm{q}, 10 \mathrm{q}, 11 \mathrm{q}, 16 \mathrm{q}, 17 \mathrm{q}$, and $19 \mathrm{q}$ in AS. The KIR genes are located on chromosome $19 \mathrm{q} 13.4$ in the LCR, and obviously are good candidates for AS susceptibility (Carter, et al., 2007). More recent investigations using different approaches like the report of the TASC/WTCCC2, did not identify this chromosome region as involved in AS susceptibility (Consortium TASC/WTCCC2, 2011). The influence of KIR/HLA genotypes in AS susceptibility may be mediated by a general imbalance between the protective/inhibitory and the risk/activating allotypes. Further studies in other populations are needed to confirm the role of KIR genes in AS susceptibility. 


\subsection{ANKH}

The ANKH gene maps to human chromosome 5 (5p15.1) and encodes a 492 amino acid multiple-pass transmembrane protein (ANK) which transports the inorganic pyrophosphate (PPi) across the plasma membrane into the extracellular compartment (Gurley, K.A., et al., 2006b). ANK function is essential in joints to inhibit mineral formation in joints and maintain mobility (Gurley, K. A., et al., 2006a). Mutations in the ANKH gene have been consistently associated with two autosomal dominant skeletal disorders: familial chondrocalcinosis (MIM \#118600) and craniometaphyseal dysplasia (MIM \#123000).

In the last decade, a very small number of reports suggested an association of ANKH with AS. In 2003, two polymorphisms - ANKH-OR and ANKH-TR - in complete linkage disequilibrium, located in the $5^{\prime}$-noncoding region and in the promoter region of this gene, respectively, were found to be significantly associated with AS. After linkage analysis and family-based association studies the authors concluded that ANKH could be among the most important non-MHC loci for AS susceptibility (Tsui, F W, et al., 2003). In a follow-up study, with 201 multiplex AS families, it was reported that the region associated with AS in women only showed significance in the test of interaction among the subset of families with affected individuals of both genders. These findings supported the concept that ANKH plays a role in genetic susceptibility to AS revealing a gender-genotype specificity in this interaction (Tsui, $\mathrm{H} \mathrm{W}$, et al., 2005). Contradicting these results, a small study performed in a cohort of 233 patients and 478 controls, revealed no association between ANKH locus and either susceptibility to AS or its clinical manifestations (Timms, A E, et al., 2003).

In another study, the authors examined a total of 45 SNPs in 15 genes by a sequential screening. 170 Japanese AS patients and 896 controls for the SNPs were first genotyped. Then, eight SNPs with $\mathrm{P}<0.05$ in the first screen were genotyped for 108 additional Japanese patients. The replication of the association of the most significant SNP was checked by genotyping 219 Taiwanese AS patients and 185 controls. After combining the first and second screens, four SNPs showed nominal significance of $\mathrm{P}<0.05$. One synonymous SNP in $A N K H$, c.963T > G, showed a marginal association in the Japanese population $(\mathrm{P}=0.045)$ (Furuichi, et al., 2008). This association is not consistent and was not replicated in recent GWAS studies with large cohorts.

\subsection{TGFB1}

The TGFB1 gene codifies for the human transforming growth factor $\beta 1$ (TGF $\beta 1$ ) (van der Paardt, et al., 2005b) located on chromosome 19q21.1. It is a multifunctional cytokine involved in inflammation, fibrosis and bone remodelling (Reveille, J D, 2011). The concentration of TGF $\beta 1$ in cartilage and bone is 100 times superior to other tissues (Centrella, et al., 1991). It was demonstrate that injections of TGF $\beta 1$ into young rat bone induce formation of cartilaginous mass and subsequently bone tissue (Joyce, et al., 1990). Whether the effect is positive with growing bones or negative with damaged bones depends on the concentration of TGF $\beta 1$ and the presence of other hormones (Archer \& Keat, 1999). Therefore, TGF $\beta 1$ represent a good candidate for a key cytokine in a disease characterized by chronic inflammation of the sacroiliac joints.

A marginal association between TGFB1 and AS was observed in a study of Finnish and British families (Jaakkola, et al., 2004) and in a Scottish case study (McGarry, et al., 2002). 
The Scottish genotype showed a strong correlation with high concentration of TGF $\beta 1$. On the other side, no significant association with AS susceptibility was reported in two following studies in Dutch and Southern Chinese populations (Howe, et al., 2005; van der Paardt, et al., 2005b); although, in the Dutch study, the frequency of mutated allele was greater in AS patients than in the healthy individuals. The TGFB1 polymorphism might be implicated to the AS disease at bone formation level but further studies are necessary. Understanding the role of TGF $\beta 1$ in AS could be interesting especially to develop new pharmacological approaches in order to prevent the disorder (van der Paardt, et al., 2005b).

\subsection{CD14}

The Cluster of differentiation 14 (CD14) gene maps to chromosome 5 (5q22-q3215q31.1) and encodes 2 protein forms: a 50 to $55 \mathrm{kD}$ glycosylphosphatidylinositol-anchored membrane protein (mCD14) and a monocyte or liver-derived soluble serum protein (sCD14) that lacks the anchor. Both molecules are essential for lipopolysaccharide (LPS)-dependent signal transduction. Increased sCD14 levels are associated with inflammatory infectious diseases and high mortality in gram-negative shock (LeVan, et al., 2001).

A putative role of CD14 in the pathogenesis of AS was investigated due to its significant role on the innate immune system. The polymorphism C-260T was studied in genomic DNA from 113 unrelated Dutch AS patients and 170 healthy controls. No significant differences were found between the frequency of this allele in patients and controls suggesting that this polymorphism is not involved in the susceptibility to AS (van der Paardt, et al., 2005a). On the other hand, evidence of association was identified between this allele and AS in a small cohort of Finnish families (Pointon, et al., 2008). No other studies about CD14 and its association with AS have been published suggesting that this association is not established.

\subsection{TNAP}

Tissue-Nonspecific Alkaline Phosphatase (TNAP) is an isozyme of a family of four homologous human alkaline phosphatase genes. It is present in the matrix vesicles and has the ability of hydrolyze PPi. In humans, this enzyme is enconded by the gene TNAP, that maps in chromosome 1, containing 12 exons. Deactivating mutations in the TNAP gene cause hypophosphatasia [MIM\#241500 (Infantile form), MIM\#146300 (Adult type)], characterized by poorly mineralized cartilage and bones, spontaneous bone fractures, chondrocalcinosis by calcium pyrophosphate deposition and elevated concentrations of pyrophosphate (PPi) (Mornet, et al., 1998).

One study has shown the significant association of the TNAP haplotype rs3767155(G) / rs3738099 (G) / rs1780329 (T) with AS but in men only (Tsui, H. W., et al., 2007). This association was later investigated in a case control study involving a cohort of 353 AS patients and 514 unrelated healthy controls, and a family-based association study with 57 pedigrees, of the Chinese Han population. Two intronic SNPs (rs3767155 and rs1780329) were genotyped; the results showed no significant difference in allele, genotype or haplotype frequencies between AS patients and controls (Cheng, et al., 2009). No other studies have replicated the association of TNAP to AS. 


\section{Conclusion}

AS susceptibility is no longer an HLA-B27 exclusive. The association of AS and ERAP1, IL23R and the intergenic regions 2p15 and 21q22 has been confirmed in large cohort studies. This knowledge increased the complexity of genes involved in AS susceptibility; however, it is shortening the way to a better understanding about AS immunopathogenesis.

The identification of associated genetic regions outside MHC will require a large number of replicates in populations with different ethnic backgrounds. The consistent data already obtained, and the results that will come up from new replicates, should provide a solid basis to new research that may unravel the mechanisms underlying all these associations. Consequently, the AS pathway will start to present an even more conclusive and consistent shape, providing new tools to clinicians and allowing an improvement in the disease diagnosis and treatment. More, the identified and confirmed markers could be used to create a complete diagnosis testing panel, along with HLA-B27.

\section{References}

Archer, J. R. \& A. C. Keat. (1999). Ankylosing spondylitis: time to focus on ankylosis. J Rheumatol,Vol. 26, No. 4, (Apr), pp. (761-4), 0315-162X

Armaka, M., M. Apostolaki, P. Jacques, D. L. Kontoyiannis, D. Elewaut \& G. Kollias. (2008). Mesenchymal cell targeting by TNF as a common pathogenic principle in chronic inflammatory joint and intestinal diseases. J Exp Med,Vol. 205, No. 2, (Feb 18), pp. (331-7), 1540-9538 (Electronic), 0022-1007 (Linking)

Armas, J. B., S. Gonzalez, J. Martinez-Borra, F. Laranjeira, E. Ribeiro, J. Correia, M. L. Ferreira, M. Toste, A. Lopez-Vazquez \& C. Lopez-Larrea. (1999). Susceptibility to ankylosing spondylitis is independent of the Bw4 and Bw6 epitopes of HLA-B27 alleles. Tissue Antigens, Vol. 53, No. 3, pp. (237-43),

Baer, A. N., C. B. McAllister, G. R. Wilkinson, R. L. Woosley \& T. Pincus. (1986). Altered distribution of debrisoquine oxidation phenotypes in patients with systemic lupus erythematosus. Arthritis Rheum,Vol. 29, No. 7, (Jul), pp. (843-50), 0004-3591 (Print), 0004-3591 (Linking)

Ball, E. J. \& M. A. Khan. (2001). HLA-B27 polymorphism. Joint Bone Spine,Vol. 68, No. 5, (October 2001), pp. (378-382),

Bang, S. Y., T. H. Kim, B. Lee, E. Kwon, S. H. Choi, K. S. Lee, S. C. Shim, A. Pope, P. Rahman, J. D. Reveille \& R. D. Inman. (2011). Genetic studies of ankylosing spondylitis in Koreans confirm associations with ERAP1 and 2p15 reported in white patients. $J$ Rheumatol,Vol. 38, No. 2, (Feb), pp. (322-4), 0315-162X

Belladonna, M. L., J. C. Renauld, R. Bianchi, C. Vacca, F. Fallarino, C. Orabona, M. C. Fioretti, U. Grohmann \& P. Puccetti. (2002). IL-23 and IL-12 have overlapping, but distinct, effects on murine dendritic cells. J Immunol,Vol. 168, No. 11, (Jun 1), pp. (5448-54), 0022-1767

Beyeler, C., M. Armstrong, H. A. Bird, J. R. Idle \& A. K. Daly. (1996). Relationship between genotype for the cytochrome P450 CYP2D6 and susceptibility to ankylosing spondylitis and rheumatoid arthritis. Ann Rheum Dis,Vol. 55, No. 1, (Jan), pp. (668), 0003-4967 (Print) 
Brionez, T. F. \& J. D. Reveille. (2008). The contribution of genes outside the major histocompatibility complex to susceptibility to ankylosing spondylitis. Curr Opin Rheumatol,Vol. 20, No. 4, (Jul), pp. (384-91), 1040-8711

Brown, M. A., K. D. Pile, L. G. Kennedy, A. Calin, C. Darke, J. Bell, B. P. Wordsworth \& F. Cornelis. (1996). HLA class I associations of ankylosing spondylitis in the white population in the United Kingdom. Annals of the Rheumatic Diseases,Vol. 55, No. 4, (April 1996), pp. (268-70),

Brown, M. A., L. G. Kennedy, A. J. MacGregor, C. Darke, E. Duncan, J. L. Shatford, A. Taylor, A. Calin \& P. Wordsworth. (1997). Susceptibility to ankylosing spondylitis in twins: the role of genes, HLA, and the environment. Arthritis Rheum,Vol. 40, No. 10, (October 1997), pp. (1823-1828),

Brown, M. A., L. G. Kennedy, C. Darke, K. Gibson, K. D. Pile, J. L. Shatford, A. Calin \& B. P. Wordsworth. (1998a). The effect of HLA-DR genes on susceptibility to and severity of ankylosing spondylitis. Arthritis Rheum,Vol. 41, No. 3, (March 1998), pp. (460465),

Brown, M. A., K. D. Pile, L. G. Kennedy, D. Campbell, L. Andrew, R. March, J. L. Shatford, D. E. Weeks, A. Calin \& B. P. Wordsworth. (1998b). A genome wide-screen for susceptibility loci in ankylosing spondylitis. Arthritis Rheum,Vol. 41, No. 4, (April 1998), pp. (588-595),

Brown, M. A., S. Edwards, E. Hoyle, S. Campbell, S. Laval, A. K. Daly, K. D. Pile, A. Calin, A. Ebringer, D. E. Weeks \& B. P. Wordsworth. (2000). Polymorphisms of the CYP2D6 gene increase susceptibility to ankylosing spondylitis. Hum Mol Genet,Vol. 9, No. 11, (Jul 1), pp. (1563-6), 0964-6906 (Print), 0964-6906 (Linking)

Brown, M. A. (2006). Non-major-histocompatibility-complex genetics of ankylosing spondylitis. Best Pract Res Clin Rheumatol,Vol. 20, No. 3, (Jun), pp. (611-21), 15216942 (Print), 1521-6942 (Linking)

Brown, M. A. (2010). Genetics of ankylosing spondylitis. Curr Opin Rheumatol,Vol. 22, No. 2, (March 2010), pp. (126-132), 1531-6963 (Electronic)

Campbell, E. C., F. Fettke, S. Bhat, K. D. Morley \& S. J. Powis. (2011). Expression of MHC class I dimers and ERAP1 in an ankylosing spondylitis patient cohort. Immunology,Vol. 133, No. 3, (Jul), pp. (379-85), 1365-2567 (Electronic), 0019-2805 (Linking)

Cargill, M., S. J. Schrodi, M. Chang, V. E. Garcia, R. Brandon, K. P. Callis, N. Matsunami, K. G. Ardlie, D. Civello, J. J. Catanese, D. U. Leong, J. M. Panko, L. B. McAllister, C. B. Hansen, J. Papenfuss, S. M. Prescott, T. J. White, M. F. Leppert, G. G. Krueger \& A. B. Begovich. (2007). A large-scale genetic association study confirms IL12B and leads to the identification of IL23R as psoriasis-risk genes. Am J Hum Genet,Vol. 80, No. 2, (Feb), pp. (273-90), 0002-9297 (Print), 0002-9297 (Linking)

Carter, K. W., A. Pluzhnikov, A. E. Timms, C. Miceli-Richard, C. Bourgain, B. P. Wordsworth, H. Jean-Pierre, N. J. Cox, L. J. Palmer, M. Breban, J. D. Reveille \& M. A. Brown. (2007). Combined analysis of three whole genome linkage scans for Ankylosing Spondylitis. Rheumatology (Oxford),Vol. 46, No. 5, (May), pp. (763-71), 1462-0324

Centrella, M., T. L. McCarthy \& E. Canalis. (1991). Transforming growth factor-beta and remodeling of bone. J Bone Joint Surg Am,Vol. 73, No. 9, (Oct), pp. (1418-28), 00219355 
Chen, C., X. Zhang \& Y. Wang. (2010). ANTXR2 and IL-1R2 polymorphisms are not associated with ankylosing spondylitis in Chinese Han population. Rheumatol Int,Vol. (Jul 21), 1437-160X (Electronic), 0172-8172 (Linking)

Chen, N. J., Chio, II, W. J. Lin, G. Duncan, H. Chau, D. Katz, H. L. Huang, K. A. Pike, Z. Hao, Y. W. Su, K. Yamamoto, R. F. de Pooter, J. C. Zuniga-Pflucker, A. Wakeham, W. C. Yeh \& T. W. Mak. (2008). Beyond tumor necrosis factor receptor: TRADD signaling in toll-like receptors. Proc Natl Acad Sci U S A,Vol. 105, No. 34, (Aug 26), pp. (12429-34), 1091-6490 (Electronic), 0027-8424 (Linking)

Chen, R., L. Yao, T. Meng \& W. Xu. (2011). The association between seven ERAP1 polymorphisms and ankylosing spondylitis susceptibility: a meta-analysis involving 8,530 cases and 12,449 controls. Rheumatol Int,Vol. (Jan 13), pp. 1437-160X (Electronic), 0172-8172 (Linking)

Cheng, N., Q. Cai, M. Fang, S. Duan, J. Lin, J. Hu, R. Chen \& S. Sun. (2009). No significant association between genetic polymorphisms in the TNAP gene and ankylosing spondylitis in the Chinese Han population. Rheumatol Int,Vol. 29, No. 3, (Jan), pp. (305-10), 0172-8172 (Print), 0172-8172 (Linking)

Chinnaiyan, A. M., K. O'Rourke, G. L. Yu, R. H. Lyons, M. Garg, D. R. Duan, L. Xing, R. Gentz, J. Ni \& V. M. Dixit. (1996). Signal transduction by DR3, a death domaincontaining receptor related to TNFR-1 and CD95. Science,Vol. 274, No. 5289, (Nov 8), pp. (990-2), 0036-8075 (Print), 0036-8075 (Linking)

Choi, C. B., T. H. Kim, J. B. Jun, H. S. Lee, S. C. Shim, B. Lee, A. Pope, M. Uddin, P. Rahman \& R. D. Inman. (2010). ARTS1 polymorphisms are associated with ankylosing spondylitis in Koreans. Ann Rheum Dis,Vol. 69, No. 3, (Mar), pp. (582-4), 1468-2060 (Electronic), 0003-4967 (Linking)

Cholerton, S., A. K. Daly \& J. R. Idle. (1992). The role of individual human cytochromes P450 in drug metabolism and clinical response. Trends Pharmacol Sci,Vol. 13, No. 12, (Dec), pp. (434-9), 0165-6147 (Print), 0165-6147 (Linking)

Chou, C. T., A. E. Timms, J. C. Wei, W. C. Tsai, B. P. Wordsworth \& M. A. Brown. (2006). Replication of association of IL1 gene complex members with ankylosing spondylitis in Taiwanese Chinese. Ann Rheum Dis,Vol. 65, No. 8, (Aug), pp. (11069), 0003-4967 (Print), 0003-4967 (Linking)

Consortium TASC. (2010). Genome-wide association study of ankylosing spondylitis identifies non-MHC susceptibility loci. Nat Genet,Vol. 42, No. 2, (Feb), pp. (123-7), 1546-1718 (Electronic), 1061-4036 (Linking)

Consortium TASC/WTCCC2. (2011). Interaction between ERAP1 and HLA-B27 in ankylosing spondylitis implicates peptide handling in the mechanism for HLA-B27 in disease susceptibility. Nat Genet,Vol. (Jul 10 - [Epub]), pp. 1546-1718 (Electronic), 1061-4036 (Linking)

Consortium WTCCC/TASC. (2007). Association scan of 14,500 nonsynonymous SNPs in four diseases identifies autoimmunity variants. Nat Genet,Vol. 39, No. 11, (Nov), pp. (1329-37), 1546-1718 (Electronic), 1061-4036 (Linking)

Cua, D. J., J. Sherlock, Y. Chen, C. A. Murphy, B. Joyce, B. Seymour, L. Lucian, W. To, S. Kwan, T. Churakova, S. Zurawski, M. Wiekowski, S. A. Lira, D. Gorman, R. A. Kastelein \& J. D. Sedgwick. (2003). Interleukin-23 rather than interleukin-12 is the critical cytokine for autoimmune inflammation of the brain. Nature,Vol. 421, No. 6924, (Feb 13), pp. (744-8), 0028-0836 (Print), 0028-0836 (Linking)

Cui, X., F. Hawari, S. Alsaaty, M. Lawrence, C. A. Combs, W. Geng, F. N. Rouhani, D. Miskinis \& S. J. Levine. (2002). Identification of ARTS-1 as a novel TNFR1-binding 
protein that promotes TNFR1 ectodomain shedding. J Clin Invest,Vol. 110, No. 4, (Aug), pp. (515-26), 0021-9738 (Print), 0021-9738 (Linking)

Cui, X., F. N. Rouhani, F. Hawari \& S. J. Levine. (2003a). Shedding of the type II IL-1 decoy receptor requires a multifunctional aminopeptidase, aminopeptidase regulator of TNF receptor type 1 shedding. J Immunol,Vol. 171, No. 12, (Dec 15), pp. (6814-9), 0022-1767 (Print), 0022-1767 (Linking)

Cui, X., F. N. Rouhani, F. Hawari \& S. J. Levine. (2003b). An aminopeptidase, ARTS-1, is required for interleukin-6 receptor shedding. J Biol Chem,Vol. 278, No. 31, (Aug 1), pp. (28677-85), 0021-9258 (Print), 0021-9258 (Linking)

Daly, A. K., S. Cholerton, M. Armstrong \& J. R. Idle. (1994). Genotyping for polymorphisms in xenobiotic metabolism as a predictor of disease susceptibility. Environ Health Perspect,Vol. 102 Suppl 9, (Nov), pp. (55-61), 0091-6765 (Print), 0091-6765 (Linking)

Danoy, P., K. Pryce, J. Hadler, L. A. Bradbury, C. Farrar, J. Pointon, M. Ward, M. Weisman, J. D. Reveille, B. P. Wordsworth, M. A. Stone, W. P. Maksymowych, P. Rahman, D. Gladman, R. D. Inman \& M. A. Brown. (2010). Association of variants at 1q32 and STAT3 with ankylosing spondylitis suggests genetic overlap with Crohn's disease. PLoS Genet,Vol. 6, No. 12, pp. (e1001195), 1553-7404 (Electronic), 1553-7390 (Linking)

Davidson, S. I., X. Wu, Y. Liu, M. Wei, P. A. Danoy, G. Thomas, Q. Cai, L. Sun, E. Duncan, N. Wang, Q. Yu, A. Xu, Y. Fu, M. A. Brown \& H. Xu. (2009). Association of ERAP1, but not IL23R, with ankylosing spondylitis in a Han Chinese population. Arthritis Rheum,Vol. 60, No. 11, (Nov), pp. (3263-8), 0004-3591 (Print), 0004-3591 (Linking)

Diaz-Pena, R., M. A. Blanco-Gelaz, B. Suarez-Alvarez, J. Martinez-Borra, A. Lopez-Vazquez, R. Alonso-Arias, J. Bruges-Armas, J. R. Vidal-Castineira \& C. Lopez-Larrea. (2008). Activating KIR genes are associated with ankylosing spondylitis in Asian populations. Hum Immunol,Vol. 69, No. 7, (Jul), pp. (437-42), 0198-8859 (Print), 0198-8859 (Linking)

Diaz-Pena, R., J. R. Vidal-Castineira, R. Alonso-Arias, B. Suarez-Alvarez, J. L. Vicario, R. Solana, E. Collantes, A. Lopez-Vazquez, J. Martinez-Borra \& C. Lopez-Larrea. (2010). Association of the KIR3DS1*013 and KIR3DL1*004 alleles with susceptibility to ankylosing spondylitis. Arthritis Rheum,Vol. 62, No. 4, (Apr), pp. (1000-6), 15290131 (Electronic), 0004-3591 (Linking)

Díaz-Peña, R., A. M. Aransay, J. Bruges-Armas, A. López-Vázquez, R.-E. N, I. Mendibil, A. Sánchez, T.-A. J. C, B. F. Bettencourt, J. Mulero, E. Collantes \& C. López-Larrea. (2011). Fine Mapping of Major Histocompatibility Complex in Ankylosing Spondylitis: Association od HLA-DPA1 and HLA-DPB1 region. In press, Vol. pp.

Dinarello, C. A. (2002). The IL-1 family and inflammatory diseases. Clin Exp Rheumatol,Vol. 20, No. 5 Suppl 27, (Sep-Oct), pp. (S1-13), 0392-856X (Print), 0392-856X (Linking)

Djouadi, K., B. Nedelec, R. Tamouza, E. Genin, R. Ramasawmy, D. Charron, M. Delpech \& S. Laoussadi. (2001). Interleukin 1 gene cluster polymorphisms in multiplex families with spondylarthropathies. Cytokine,Vol. 13, No. 2, (Jan 21), pp. (98-103), 1043-4666 (Print), 1043-4666 (Linking)

Duerr, R. H., K. D. Taylor, S. R. Brant, J. D. Rioux, M. S. Silverberg, M. J. Daly, A. H. Steinhart, C. Abraham, M. Regueiro, A. Griffiths, T. Dassopoulos, A. Bitton, H. Yang, S. Targan, L. W. Datta, E. O. Kistner, L. P. Schumm, A. T. Lee, P. K. Gregersen, M. M. Barmada, J. I. Rotter, D. L. Nicolae \& J. H. Cho. (2006). A genomewide association study identifies IL23R as an inflammatory bowel disease gene. 
Science,Vol. 314, No. 5804, (Dec 1), pp. (1461-3), 1095-9203 (Electronic), 0036-8075 (Linking)

Dunne, A. \& L. A. O'Neill. (2003). The interleukin-1 receptor/Toll-like receptor superfamily: signal transduction during inflammation and host defense. Sci STKE,Vol. 2003, No. 171, (Feb 25), pp. (re3), 1525-8882 (Electronic), 1525-8882 (Linking)

Erden, G., F. S. Acar, E. E. Inal, A. O. Soydas, K. Ozoran, H. Bodur \& M. M. Yildirimkaya. (2009). Frequency of mutated allele CYP2D6*4 in the Turkish ankylosing spondylitis patients and healthy controls. Rheumatol Int,Vol. 29, No. 12, (Oct), pp. (1431-4), 1437-160X (Electronic), 0172-8172 (Linking)

Furuichi, T., K. Maeda, C. T. Chou, Y. F. Liu, T. C. Liu, Y. Miyamoto, A. Takahashi, K. Mori, K. Ikari, N. Kamatani, H. Kurosawa, H. Inoue, S. F. Tsai \& S. Ikegawa. (2008). Association of the MSX2 gene polymorphisms with ankylosing spondylitis in Japanese. J Hum Genet,Vol. 53, No. 5, pp. (419-24), 1434-5161 (Print), 1434-5161 (Linking)

Garcia-Fernandez, S., S. Gonzalez, J. Martinez-Borra, M. Blanco-Gelaz, A. Lopez-Vazquez \& C. Lopéz-Larrea. (2001). New insights regarding HLA-B27 diversity in the Asian population. Tissue Antigenes,Vol. 58, No. 4, (October 2001), pp. (259-262),

Garcia, F., D. Rognan, J. R. Lamas, A. Marina \& L. d. C. J. A. (1998). An HLA-B27 polymorphism $\left(\mathrm{B}^{\star} 2710\right)$ that is critical for T-cell recognition has limited effects on peptide specificity. Tissue Antigens,Vol. 51, No. 1, (January 1998), pp. (1-9),

Gayle, M. A., J. L. Slack, T. P. Bonnert, B. R. Renshaw, G. Sonoda, T. Taguchi, J. R. Testa, S. K. Dower \& J. E. Sims. (1996). Cloning of a putative ligand for the T1/ST2 receptor. J Biol Chem,Vol. 271, No. 10, (Mar 8), pp. (5784-9), 0021-9258 (Print), 0021-9258 (Linking)

Gonzalez-Roces, S., M. V. Alvarez, S. Gonzalez, A. Dieye, H. Makni, D. G. Woodfield, L. Housan, V. Konenkov, M. C. Abbadi, N. Grunnet, E. Coto \& C. Lopez-Larrea. (1997). HLA-B27 polymorphism and worldwide susceptibility to ankylosing spondylitis. Tissue Antigens,Vol. 49, No. 2, (February 1997), pp. (116-123),

Gonzalez, F. J. (1992). Human cytochromes P450: problems and prospects. Trends Pharmacol Sci,Vol. 13, No. 9, (Sep), pp. (346-52), 0165-6147 (Print), 0165-6147 (Linking)

Goto, Y., H. Tanji, A. Hattori \& M. Tsujimoto. (2008). Glutamine-181 is crucial in the enzymatic activity and substrate specificity of human endoplasmic-reticulum aminopeptidase-1. Biochem J,Vol. 416, No. 1, (Nov 15), pp. (109-16), 1470-8728 (Electronic), 0264-6021 (Linking)

Gurley, K. A., H. Chen, C. Guenther, E. T. Nguyen, R. B. Rountree, M. Schoor \& D. M. Kingsley. (2006a). Mineral formation in joints caused by complete or joint-specific loss of ANK function. J Bone Miner Res,Vol. 21, No. 8, (Aug), pp. (1238-47), 08840431 (Print)

Gurley, K. A., R. J. Reimer \& D. M. Kingsley. (2006b). Biochemical and Genetic Analysis of ANK in Arthritis and Bone Disease. Am. J. Hum. Genet.,Vol. 79, pp. (1017-1029),

Harvey, D., J. J. Pointon, D. M. Evans, T. Karaderi, C. Farrar, L. H. Appleton, R. D. Sturrock, M. A. Stone, U. Oppermann, M. A. Brown \& B. P. Wordsworth. (2009a). Investigating the genetic association between ERAP1 and ankylosing spondylitis. Hum Mol Genet,Vol. 18, No. 21, (Nov 1), pp. (4204-12), 1460-2083 (Electronic), 09646906 (Linking)

Harvey, D., J. J. Pointon, C. Sleator, A. Meenagh, C. Farrar, J. Y. Sun, D. Senitzer, D. Middleton, M. A. Brown \& B. P. Wordsworth. (2009b). Analysis of killer 
immunoglobulin-like receptor genes in ankylosing spondylitis. Ann Rheum Dis,Vol. 68, No. 4, (Apr), pp. (595-8), 1468-2060 (Electronic), 0003-4967 (Linking)

Hou, T. Y., H. C. Chen, C. H. Chen, D. M. Chang, F. C. Liu \& J. H. Lai. (2007). Usefulness of human leucocyte antigen-B27 subtypes in predicting ankylosing spondylitis: Taiwan experience. Intern Med J.,Vol. 37, No. 11, (November 2007), pp. (749-752),

Howe, H. S., P. L. Cheung, K. O. Kong, H. Badsha, B. Y. Thong, K. P. Leong, E. T. Koh, T. Y. Lian, Y. K. Cheng, S. Lam, D. Teo, T. C. Lau \& B. P. Leung. (2005). Transforming growth factor beta-1 and gene polymorphisms in oriental ankylosing spondylitis. Rheumatology (Oxford),Vol. 44, No. 1, (Jan), pp. (51-4), 1462-0324 (Print), 1462-0324 (Linking)

Hsu, H., J. Xiong \& D. V. Goeddel. (1995). The TNF receptor 1-associated protein TRADD signals cell death and NF-kappa B activation. Cell,Vol. 81, No. 4, (May 19), pp. (495-504), 0092-8674 (Print), 0092-8674 (Linking)

Hsu, K. C., S. Chida, D. E. Geraghty \& B. Dupont. (2002). The killer cell immunoglobulinlike receptor (KIR) genomic region: gene-order, haplotypes and allelic polymorphism. Immunol Rev,Vol. 190, (Dec), pp. (40-52), 0105-2896 (Print), 01052896 (Linking)

Jaakkola, E., A. M. Crane, K. Laiho, I. Herzberg, A. M. Sims, L. Bradbury, A. Calin, S. Brophy, M. Kauppi, K. Kaarela, B. P. Wordsworth, J. Tuomilehto \& M. A. Brown. (2004). The effect of transforming growth factor beta1 gene polymorphisms in ankylosing spondylitis. Rheumatology (Oxford),Vol. 43, No. 1, (Jan), pp. (32-8), 14620324 (Print), 1462-0324 (Linking)

Jaakkola, E., I. Herzberg, K. Laiho, M. C. Barnardo, J. J. Pointon, M. Kauppi, K. Kaarela, E. Tuomilehto-Wolf, J. Tuomilehto, B. P. Wordsworth \& M. A. Brown. (2006). Finnish HLA studies confirm the increased risk conferred by HLA-B27 homozygosity in ankylosing spondylitis. Ann Rheum Dis,Vol. 65, No. 6, (Jun), pp. (775-80), 0003-4967 (Print), 0003-4967 (Linking)

Jandus, C., G. Bioley, J. P. Rivals, J. Dudler, D. Speiser \& P. Romero. (2008). Increased numbers of circulating polyfunctional Th17 memory cells in patients with seronegative spondylarthritides. Arthritis Rheum,Vol. 58, No. 8, (Aug), pp. (230717), 0004-3591 (Print), 0004-3591 (Linking)

Jarvinen, P. (1995). Occurrence of ankylosing spondylitis in a nationwide series of twins. Arthritis Rheum,Vol. 38, No. 3, (March 1995), pp. (381-383),

Jiao, Y. L., B. C. Zhang, L. You, J. F. Li, J. Zhang, C. Y. Ma, B. Cui, L. C. Wang, Z. J. Chen \& Y. R. Zhao. (2010). Polymorphisms of KIR gene and HLA-C alleles: possible association with susceptibility to HLA-B27-positive patients with ankylosing spondylitis. J Clin Immunol,Vol. 30, No. 6, (Nov), pp. (840-4), 1573-2592 (Electronic), 0271-9142 (Linking)

Jin, L., G. Zhang, J. M. Akey, J. Luo, J. Lee, M. H. Weisman, J. Bruckel, R. D. Inman, M. A. Stone, M. A. Khan, H. R. Schumacher, W. P. Maksymowych, M. L. Mahowald, A. D. Sawitzke, F. B. Vasey, D. T. Yu \& J. D. Reveille. (2004). Lack of linkage of IL1RN genotypes with ankylosing spondylitis susceptibility. Arthritis Rheum,Vol. 50, No. 9, (Sep), pp. (3047-8), 0004-3591 (Print), 0004-3591 (Linking)

Joyce, M. E., S. Jingushi \& M. E. Bolander. (1990). Transforming growth factor-beta in the regulation of fracture repair. Orthop Clin North Am,Vol. 21, No. 1, (Jan), pp. (199209), 0030-5898 (Print), 0030-5898 (Linking)

Karaderi, T., D. Harvey, C. Farrar, L. H. Appleton, M. A. Stone, R. D. Sturrock, M. A. Brown, P. Wordsworth \& J. J. Pointon. (2009). Association between the interleukin 23 
receptor and ankylosing spondylitis is confirmed by a new UK case-control study and meta-analysis of published series. Rheumatology (Oxford),Vol. 48, No. 4, (Apr), pp. (386-9), 1462-0332 (Electronic), 1462-0324 (Linking)

Kchir, M. M., W. Hamdi, L. Laadhar, S. Kochbati, D. Kaffel, K. Saadellaoui, H. Lahmar, M. M. Ghannouchi, D. Azzouz, L. Daoud, A. Ben Hamida, B. Zouari, M. Zitouni \& S. Makni. (2010). HLA-B, DR and DQ antigens polymorphism in Tunisian patients with ankylosing spondylitis (a case-control study). Rheumatol Int,Vol. 30, No. 7, (May), pp. (933-939), 1437-160X (Electronic), 0172-8172 (Linking)

Khan, M. A., I. Kushner \& W. E. Braun. (1980). Genetic heterogeneity in primary ankylosing sondylitis. J Rheumatol,Vol. 7, No. 3, (May 1980), pp. (383-386),

Kim, T. H., M. A. Stone, P. Rahman, D. H. Yoo, Y. W. Park, U. Payne, D. Hallett \& R. D. Inman. (2005). Interleukin 1 and nuclear factor-kappaB polymorphisms in ankylosing spondylitis in Canada and Korea. J Rheumatol,Vol. 32, No. 10, (Oct), pp. (1907-10), 0315-162X (Print), 0315-162X (Linking)

Kimura-Yoshida, C., K. Kitajima, I. Oda-Ishii, E. Tian, M. Suzuki, M. Yamamoto, T. Suzuki, M. Kobayashi, S. Aizawa \& I. Matsuo. (2004). Characterization of the pufferfish Otx2 cis-regulators reveals evolutionarily conserved genetic mechanisms for vertebrate head specification. Development,Vol. 131, No. 1, (Jan), pp. (57-71), 09501991 (Print), 0950-1991 (Linking)

Kochan, G., T. Krojer, D. Harvey, R. Fischer, L. Chen, M. Vollmar, F. von Delft, K. L. Kavanagh, M. A. Brown, P. Bowness, P. Wordsworth, B. M. Kessler \& U. Oppermann. (2011). Crystal structures of the endoplasmic reticulum aminopeptidase-1 (ERAP1) reveal the molecular basis for N-terminal peptide trimming. Proc Natl Acad Sci U S A,Vol. 108, No. 19, (May 10), pp. (7745-50), 10916490 (Electronic), 0027-8424 (Linking)

Kugathasan, S., R. N. Baldassano, J. P. Bradfield, P. M. Sleiman, M. Imielinski, S. L. Guthery, S. Cucchiara, C. E. Kim, E. C. Frackelton, K. Annaiah, J. T. Glessner, E. Santa, T. Willson, A. W. Eckert, E. Bonkowski, J. L. Shaner, R. M. Smith, F. G. Otieno, N. Peterson, D. J. Abrams, R. M. Chiavacci, R. Grundmeier, P. Mamula, G. Tomer, D. A. Piccoli, D. S. Monos, V. Annese, L. A. Denson, S. F. Grant \& H. Hakonarson. (2008). Loci on $20 \mathrm{q} 13$ and $21 \mathrm{q} 22$ are associated with pediatric-onset inflammatory bowel disease. Nat Genet,Vol. 40, No. 10, (Oct), pp. (1211-5), 1546-1718 (Electronic), 1061-4036 (Linking)

Lanier, L. L., B. C. Corliss, J. Wu, C. Leong \& J. H. Phillips. (1998). Immunoreceptor DAP12 bearing a tyrosine-based activation motif is involved in activating NK cells. Nature,Vol. 391, No. 6668, (Feb 12), pp. (703-7), 0028-0836 (Print), 0028-0836 (Linking)

Laval, S. H., A. Timms, S. Edwards, L. Bradbury, S. Brophy, A. Milicic, L. Rubin, K. A. Siminovitch, D. E. Weeks, A. Calin, B. P. Wordsworth \& M. A. Brown. (2001). Whole-genome screening in ankylosing spondylitis: evidence of non-MHC geneticsusceptibility loci. Am J Hum Genet,Vol. 68, No. 4, (Apr), pp. (918-26), 0002-9297 (Print), 0002-9297 (Linking)

LeVan, T. D., J. W. Bloom, T. J. Bailey, C. L. Karp, M. Halonen, F. D. Martinez \& D. Vercelli. (2001). A common single nucleotide polymorphism in the CD14 promoter decreases the affinity of $\mathrm{Sp}$ protein binding and enhances transcriptional activity. $J$ Immunol,Vol. 167, No. 10, (Nov 15), pp. (5838-44), 0022-1767 (Print), 0022-1767 (Linking) 
Liu, Y., L. Jiang, Q. Cai, P. Danoy, M. C. Barnardo, M. A. Brown \& H. Xu. (2010). Predominant association of HLA-B 2704 with ankylosing spondylitis in Chinese Han patients. Tissue Antigens, Vol. 75, No. 1, (January 2010), pp. (61-64),

Lopez-Larrea, C., K. Sujirachato, N. K. Mehra, P. Chiewsilp, D. Isarangkura, U. Kanga, O. Dominguez, E. Coto, M. Pena \& F. Setien. (1995). HLA-B27 subtypes in Asian patients with ankylosing spondylitis. Evidence for new associations. Tissue Antigens,Vol. 45, No. 3, (March 1995), pp. (1698- 76),

Lopez-Larrea, C., M. Mijiyawa, S. Gonzalez, J. L. Fernandez-Morera, M. A. Blanco-Gelaz, J. Martinez-Borra \& A. Lopez-Vazquez. (2002). Association of Ankylosing Spondylitis with HLA-B*1403 in a West African population. Arthritis Rheum,Vol. 46, No. 11, (November 2002), pp. (2968- 2971),

Lopez-Larrea, C., M. A. Blanco-Gelaz, J. C. Torre-Alonso, J. Bruges Armas, B. SuarezAlvarez, L. Pruneda, A. R. Couto, S. Gonzalez, A. Lopez-Vazquez \& J. MartinezBorra. (2006). Contribution of KIR3DL1/3DS1 to ankylosing spondylitis in human leukocyte antigen-B27 Caucasian populations. Arthritis Res Ther,Vol. 8, No. 4, pp. (R101), 1478-6362 (Electronic), 1478-6354 (Linking)

MacLean, I. L., S. Iqball, P. Woo, A. C. Keat, R. A. Hughes, G. H. Kingsley \& S. C. Knight. (1993). HLA-B27 subtypes in the spondarthropathies. Clin Exp Immunol,Vol. 91, pp. (214-9),

Mahfoudh, N., M. Siala, M. Rihl, A. Kammoun, F. Frikha, H. Fourati, M. Younes, R. Gdoura, L. Gaddour, F. Hakim, Z. Bahloul, S. Baklouti, N. Bargaoui, S. Sellami, A. Hammami \& H. Makni. (2011). Association and frequency of HLA-A, B and HLADR genes in south Tunisian patients with spondyloarthritis (SpA). Clin Rheumatol,Vol. (Mar 1), pp. 1434-9949 (Electronic), 0770-3198 (Linking)

Maksymowych, W. P., S. Tao, J. Vaile, M. Suarez-Almazor, C. Ramos-Remus \& A. S. Russell. (2000). LMP2 polymorphism is associated with extraspinal disease in HLA-B27 negative Caucasian and Mexican Mestizo patients with ankylosing spondylitis. $J$ Rheumatol.,Vol. 27, No. 1, (January 2000), pp. (183-189),

Maksymowych, W. P., J. P. Reeve, J. D. Reveille, J. M. Akey, H. Buenviaje, L. O'Brien, P. M. Peloso, G. T. Thomson, L. Jin \& A. S. Russell. (2003). High-throughput singlenucleotide polymorphism analysis of the IL1RN locus in patients with ankylosing spondylitis by matrix-assisted laser desorption ionization-time-of-flight mass spectrometry. Arthritis Rheum,Vol. 48, No. 7, (Jul), pp. (2011-8), 0004-3591 (Print), 0004-3591 (Linking)

Maksymowych, W. P., P. Rahman, J. P. Reeve, D. D. Gladman, L. Peddle \& R. D. Inman. (2006). Association of the IL1 gene cluster with susceptibility to ankylosing spondylitis: an analysis of three Canadian populations. Arthritis Rheum,Vol. 54, No. 3, (Mar), pp. (974-85), 0004-3591 (Print), 0004-3591 (Linking)

Maksymowych, W. P., R. D. Inman, D. D. Gladman, J. P. Reeve, A. Pope \& P. Rahman. (2009). Association of a specific ERAP1/ARTS1 haplotype with disease susceptibility in ankylosing spondylitis. Arthritis Rheum,Vol. 60, No. 5, (May), pp. (1317-23), 0004-3591 (Print), 0004-3591 (Linking)

McGarry, F., L. Cousins, R. D. Sturrock \& M. Field. (2002). A polymorphism within the Transforming Growth Factor $\beta 1$ gene is associated with ankylosing spondylitis (AS). Arthritis Res,Vol. 4, No. Suppl 1, (Feb 2002), pp. (22),

Miceli-Richard, C., H. Zouali, R. Said-Nahal, S. Lesage, F. Merlin, C. De Toma, H. Blanche, M. Sahbatou, M. Dougados, G. Thomas, M. Breban \& J. P. Hugot. (2004). Significant 
linkage to spondyloarthropathy on 9q31-34. Hum Mol Genet,Vol. 13, No. 15, (Aug 1), pp. (1641-8), 0964-6906 (Print), 0964-6906 (Linking)

Migone, T. S., J. Zhang, X. Luo, L. Zhuang, C. Chen, B. Hu, J. S. Hong, J. W. Perry, S. F. Chen, J. X. Zhou, Y. H. Cho, S. Ullrich, P. Kanakaraj, J. Carrell, E. Boyd, H. S. Olsen, G. Hu, L. Pukac, D. Liu, J. Ni, S. Kim, R. Gentz, P. Feng, P. A. Moore, S. M. Ruben \& P. Wei. (2002). TL1A is a TNF-like ligand for DR3 and TR6/DcR3 and functions as a T cell costimulator. Immunity,Vol. 16, No. 3, (Mar), pp. (479-92), 1074-7613 (Print), 1074-7613 (Linking)

Moritz, D. R., H. R. Rodewald, J. Gheyselinck \& R. Klemenz. (1998). The IL-1 receptorrelated T1 antigen is expressed on immature and mature mast cells and on fetal blood mast cell progenitors. J Immunol,Vol. 161, No. 9, (Nov 1), pp. (4866-74), 00221767 (Print), 0022-1767 (Linking)

Mornet, E., A. Taillandier, S. Peyramaure, F. Kaper, F. Muller, R. Brenner, P. Bussière, P. Freisinger, J. Godard, M. Le Merrer, J. F. Oury, H. Plauchu, R. Puddu, J. M. Rival, A. Superti-Furga, R. L. Touraine, J. L. Serre \& B. Simon-Bouy. (1998). Identification of fifteen nvel mutations in the tissue-nonspecific alkaline phosphatase (TNSALP) gene in European patients with severe hypophosphatasia. Eur J Hum Genet,Vol. 6, pp. (308-314),

Mulero, J. J., A. M. Pace, S. T. Nelken, D. B. Loeb, T. R. Correa, R. Drmanac \& J. E. Ford. (1999). IL1HY1: A novel interleukin-1 receptor antagonist gene. Biochem Biophys Res Commun,Vol. 263, No. 3, (Oct 5), pp. (702-6), 0006-291X (Print), 0006-291X (Linking)

Murphy, C. A., C. L. Langrish, Y. Chen, W. Blumenschein, T. McClanahan, R. A. Kastelein, J. D. Sedgwick \& D. J. Cua. (2003). Divergent pro- and antiinflammatory roles for IL23 and IL-12 in joint autoimmune inflammation. J Exp Med,Vol. 198, No. 12, (Dec 15), pp. (1951-7), 0022-1007 (Print), 0022-1007 (Linking)

Nobrega, M. A., I. Ovcharenko, V. Afzal \& E. M. Rubin. (2003). Scanning human gene deserts for long-range enhancers. Science,Vol. 302, No. 5644, (Oct 17), pp. (413), 1095-9203 (Electronic), 0036-8075 (Linking)

Nunez, C., B. Dema, M. C. Cenit, I. Polanco, C. Maluenda, R. Arroyo, V. de las Heras, M. Bartolome, E. G. de la Concha, E. Urcelay \& A. Martinez. (2008). IL23R: a susceptibility locus for celiac disease and multiple sclerosis? Genes Immun,Vol. 9, No. 4, (Jun), pp. (289-93), 1476-5470 (Electronic), 1466-4879 (Linking)

Oppmann, B., R. Lesley, B. Blom, J. C. Timans, Y. Xu, B. Hunte, F. Vega, N. Yu, J. Wang, K. Singh, F. Zonin, E. Vaisberg, T. Churakova, M. Liu, D. Gorman, J. Wagner, S. Zurawski, Y. Liu, J. S. Abrams, K. W. Moore, D. Rennick, R. de Waal-Malefyt, C. Hannum, J. F. Bazan \& R. A. Kastelein. (2000). Novel p19 protein engages IL-12p40 to form a cytokine, IL-23, with biological activities similar as well as distinct from IL-12. Immunity,Vol. 13, No. 5, (Nov), pp. (715-25), 1074-7613 (Print), 1074-7613 (Linking)

Ovcharenko, I., G. G. Loots, M. A. Nobrega, R. C. Hardison, W. Miller \& L. Stubbs. (2005). Evolution and functional classification of vertebrate gene deserts. Genome Res,Vol. 15, No. 1, (Jan), pp. (137-45), 1088-9051 (Print), 1088-9051 (Linking)

Pappu, B. P., A. Borodovsky, T. S. Zheng, X. Yang, P. Wu, X. Dong, S. Weng, B. Browning, M. L. Scott, L. Ma, L. Su, Q. Tian, P. Schneider, R. A. Flavell, C. Dong \& L. C. Burkly. (2008). TL1A-DR3 interaction regulates Th17 cell function and Th17mediated autoimmune disease. J Exp Med,Vol. 205, No. 5, (May 12), pp. (1049-62), 1540-9538 (Electronic), 0022-1007 (Linking) 
Parham, C., M. Chirica, J. Timans, E. Vaisberg, M. Travis, J. Cheung, S. Pflanz, R. Zhang, K. P. Singh, F. Vega, W. To, J. Wagner, A. M. O'Farrell, T. McClanahan, S. Zurawski, C. Hannum, D. Gorman, D. M. Rennick, R. A. Kastelein, R. de Waal Malefyt \& K. W. Moore. (2002). A receptor for the heterodimeric cytokine IL-23 is composed of IL-12Rbeta1 and a novel cytokine receptor subunit, IL-23R. J Immunol,Vol. 168, No. 11, (Jun 1), pp. (5699-708), 0022-1767 (Print), 0022-1767 (Linking)

Parham, P. (2005). MHC class I molecules and KIRs in human history, health and survival. Nat Rev Immunol,Vol. 5, No. 3, (Mar), pp. (201-14), 1474-1733 (Print), 1474-1733 (Linking)

Park, H., Z. Li, X. O. Yang, S. H. Chang, R. Nurieva, Y. H. Wang, Y. Wang, L. Hood, Z. Zhu, Q. Tian \& C. Dong. (2005). A distinct lineage of CD4 T cells regulates tissue inflammation by producing interleukin 17. Nat Immunol,Vol. 6, No. 11, (Nov), pp. (1133-41), 1529-2908 (Print), 1529-2908 (Linking)

Parnet, P., K. E. Garka, T. P. Bonnert, S. K. Dower \& J. E. Sims. (1996). IL-1Rrp is a novel receptor-like molecule similar to the type I interleukin-1 receptor and its homologues T1/ST2 and IL-1R AcP. J Biol Chem,Vol. 271, No. 8, (Feb 23), pp. (396770), 0021-9258 (Print), 0021-9258 (Linking)

Pazar, B., E. Safrany, P. Gergely, S. Szanto, Z. Szekanecz \& G. Poor. (2010). Association of ARTS1 gene polymorphisms with ankylosing spondylitis in the Hungarian population: the rs27044 variant is associated with HLA-B*2705 subtype in Hungarian patients with ankylosing spondylitis. J Rheumatol,Vol. 37, No. 2, (Feb), pp. (379-84), 0315-162X (Print), 0315-162X (Linking)

Pimentel-Santos, F. M., D. Ligeiro, M. Matos, A. F. Mourao, E. Sousa, P. Pinto, A. Ribeiro, M. Sousa, A. Barcelos, F. Godinho, M. Cruz, J. E. Fonseca, H. Guedes-Pinto, H. Trindade, D. M. Evans, M. A. Brown \& J. C. Branco. (2009). Association of IL23R and ERAP1 genes with ankylosing spondylitis in a Portuguese population. Clin Exp Rheumatol,Vol. 27, No. 5, (Sep-Oct), pp. (800-6), 0392-856X (Print), 0392-856X (Linking)

Ploski, R., B. Flato, O. Vinje, W. Maksymowych, O. Forre \& E. Thorsby. (1995). Association to HLA-DRB1*08, HLA-DPB1*0301 and homozygosity for an HLA-linked proteasome gene in juvenile ankylosing spondylitis. Hum Immunol,Vol. 44, No. 2, (Oct), pp. (88-96), 0198-8859 (Print), 0198-8859 (Linking)

Pointon, J. J., K. Chapman, D. Harvey, A. M. Sims, L. Bradbury, K. Laiho, M. Kauppi, K. Kaarela, J. Tuomilehto, M. A. Brown \& B. P. Wordsworth. (2008). Toll-like receptor 4 and CD14 polymorphisms in ankylosing spondylitis: evidence of a weak association in Finns. J Rheumatol,Vol. 35, No. 8, (Aug), pp. (1609-12), 0315-162X (Print), 0315-162X (Linking)

Pointon, J. J., D. Harvey, T. Karaderi, L. H. Appleton, C. Farrar, M. A. Stone, R. D. Sturrock, J. D. Reveille, M. H. Weisman, M. M. Ward, M. A. Brown \& B. P. Wordsworth. (2010). The chromosome 16q region associated with ankylosing spondylitis includes the candidate gene tumour necrosis factor receptor type 1-associated death domain (TRADD). Ann Rheum Dis,Vol. 69, No. 6, (Jun), pp. (1243-6), 14682060 (Electronic), 0003-4967 (Linking)

Rahman, P., R. D. Inman, D. D. Gladman, J. P. Reeve, L. Peddle \& W. P. Maksymowych. (2008). Association of interleukin-23 receptor variants with ankylosing spondylitis. Arthritis Rheum,Vol. 58, No. 4, (Apr), pp. (1020-5), 0004-3591 (Print), 0004-3591 (Linking) 
Reveille, J. D. \& R. M. Maganti. (2009). Subtypes of HLA-B27: history and implications in the pathogenesis of ankylosing spondylitis. Adv Exp Med Bio,Vol. 649, pp. (159-176),

Reveille, J. D., A. M. Sims, P. Danoy, D. M. Evans, P. Leo, J. J. Pointon, R. Jin, X. Zhou, L. A. Bradbury, L. H. Appleton, J. C. Davis, L. Diekman, T. Doan, A. Dowling, R. Duan, E. L. Duncan, C. Farrar, J. Hadler, D. Harvey, T. Karaderi, R. Mogg, E. Pomeroy, K. Pryce, J. Taylor, L. Savage, P. Deloukas, V. Kumanduri, L. Peltonen, S. M. Ring, P. Whittaker, E. Glazov, G. P. Thomas, W. P. Maksymowych, R. D. Inman, M. M. Ward, M. A. Stone, M. H. Weisman, B. P. Wordsworth \& M. A. Brown. (2010). Genome-wide association study of ankylosing spondylitis identifies non-MHC susceptibility loci. Nat Genet,Vol. 42, No. 2, (Feb), pp. (123-7), 1546-1718 (Electronic), 1061-4036 (Linking)

Reveille, J. D. (2011). The genetic basis of spondyloarthritis. Ann Rheum Dis,Vol. 70, No. Suppl 1, (March 2011), pp. (i44-50),

Robinson, W. P., S. M. van der Linden, M. A. Khan, H. U. Rentsch, A. Cats, A. Russell \& G. Thomson. (1989). HLA-Bw60 increases susceptibility to ankylosing spondylitis in HLA-B27 + patients. Arthritis Rheum,Vol. 32, No. 9, (September 1989), pp. (11351141),

Rubin, L. A., C. I. Amos, J. A. Wade, J. R. Martin, S. J. Bale, A. H. Little, D. D. Gladman, G. E. Bonney, J. D. Rubenstein \& K. A. Siminovitch. (1994). Investigating the genetic basis for ankylosing spondylitis. Linkage studies with the major histocompatibility complex region. Arthritis Rheum,Vol. 37, No. 8, (August 1994), pp. (1212-1220),

Rueda, B., G. Orozco, E. Raya, J. L. Fernandez-Sueiro, J. Mulero, F. J. Blanco, C. Vilches, M. A. Gonzalez-Gay \& J. Martin. (2008). The IL23R Arg381Gln non-synonymous polymorphism confers susceptibility to ankylosing spondylitis. Ann Rheum Dis,Vol. 67, No. 10, (Oct), pp. (1451-4), 1468-2060 (Electronic), 0003-4967 (Linking)

Safrany, E., B. Pazar, V. Csongei, L. Jaromi, N. Polgar, C. Sipeky, I. F. Horvath, M. Zeher, G. Poor \& B. Melegh. (2009). Variants of the IL23R gene are associated with ankylosing spondylitis but not with Sjogren syndrome in Hungarian population samples. Scand J Immunol,Vol. 70, No. 1, (Jul), pp. (68-74), 1365-3083 (Electronic), 0300-9475 (Linking)

Said-Nahal, R., C. Miceli-Richard, C. Gautreau, R. Tamouza, N. Borot, R. Porcher, D. Charron, M. Dougados \& M. Breban. (2002). The role of HLA genes in familial spondyloarthropathy: a comprehensive study of 70 multiplex families. Ann Rheum Dis,Vol. 61, No. 3, (Mar), pp. (201-206), 0003-4967 (Print), 0003-4967 (Linking)

Saric, T., S. C. Chang, A. Hattori, I. A. York, S. Markant, K. L. Rock, M. Tsujimoto \& A. L. Goldberg. (2002). An IFN-gamma-induced aminopeptidase in the ER, ERAP1, trims precursors to MHC class I-presented peptides. Nat Immunol,Vol. 3, No. 12, (Dec), pp. (1169-76), 1529-2908 (Print), 1529-2908 (Linking)

Saveanu, L., O. Carroll, V. Lindo, M. Del Val, D. Lopez, Y. Lepelletier, F. Greer, L. Schomburg, D. Fruci, G. Niedermann \& P. M. van Endert. (2005). Concerted peptide trimming by human ERAP1 and ERAP2 aminopeptidase complexes in the endoplasmic reticulum. Nat Immunol,Vol. 6, No. 7, (Jul), pp. (689-97), 1529-2908 (Print), 1529-2908 (Linking)

Sims, A. M., M. Barnardo, I. Herzberg, L. Bradbury, A. Calin, B. P. Wordsworth, C. Darke \& M. A. Brown. (2007). Non-B27 MHC associations of ankylosing spondylitis. Genes Immun,Vol. 8, No. 2, (March 2007), pp. (115-123),

Sims, A. M., A. E. Timms, J. Bruges-Armas, R. Burgos-Vargas, C. T. Chou, T. Doan, A. Dowling, R. N. Fialho, P. Gergely, D. D. Gladman, R. Inman, M. Kauppi, K. 
Kaarela, K. Laiho, W. Maksymowych, J. J. Pointon, P. Rahman, J. D. Reveille, R. Sorrentino, J. Tuomilehto, G. Vargas-Alarcon, B. P. Wordsworth, H. Xu \& M. A. Brown. (2008). Prospective meta-analysis of interleukin 1 gene complex polymorphisms confirms associations with ankylosing spondylitis. Ann Rheum Dis,Vol. 67, No. 9, (Sep), pp. (1305-9), 1468-2060 (Electronic), 0003-4967 (Linking)

Steinman, L. (2007). A brief history of $\mathrm{T}(\mathrm{H}) 17$, the first major revision in the $\mathrm{T}(\mathrm{H}) 1 / \mathrm{T}(\mathrm{H}) 2$ hypothesis of $\mathrm{T}$ cell-mediated tissue damage. Nat Med,Vol. 13, No. 2, (Feb), pp. (139-45), 1078-8956 (Print), 1078-8956 (Linking)

Sung, I. H., T. H. Kim, S. Y. Bang, T. J. Kim, B. Lee, L. Peddle, P. Rahman, C. M. Greenwood, P. Hu \& R. D. Inman. (2009). IL-23R polymorphisms in patients with ankylosing spondylitis in Korea. J Rheumatol,Vol. 36, No. 5, (May), pp. (1003-5), 0315-162X (Print), 0315-162X (Linking)

Symons, J. A., J. A. Eastgate \& G. W. Duff. (1991). Purification and characterization of a novel soluble receptor for interleukin 1. J Exp Med,Vol. 174, No. 5, (Nov 1), pp. (1251-4), 0022-1007 (Print), 0022-1007 (Linking)

Takedatsu, H., K. S. Michelsen, B. Wei, C. J. Landers, L. S. Thomas, D. Dhall, J. Braun \& S. R. Targan. (2008). TL1A (TNFSF15) regulates the development of chronic colitis by modulating both T-helper 1 and T-helper 17 activation. Gastroenterology,Vol. 135, No. 2, (Aug), pp. (552-67), 1528-0012 (Electronic), 0016-5085 (Linking)

Tamouza, R., I. Mansour, N. Bouguacha, S. Klayme, K. Djouadi, S. Laoussadi, M. Azoury, N. Dulphy, R. Ramasawmy, R. Krishnamoorthy, A. Toubert, R. Naman \& D. Charron. (2001). A new HLA-B*27 allele $\left(B^{\star 2} 2719\right)$ identified in a Lebanese patient affected with ankylosing spondylitis. Tissue Antigens,Vol. 58, No. 1, (July 2001), pp. (30-3),

Thomas, G. P. \& M. A. Brown. (2010). Genetics and genomics of ankylosing spondylitis. Immunol Rev,Vol. 233, No. 1, (Jan), pp. (162-80), 1600-065X (Electronic), 0105-2896 (Linking)

Timms, A. E., Y. Zhang, L. Bradbury, B. P. Wordsworth \& M. A. Brown. (2003). Investigation of the role of ANKH in ankylosing spondylitis. Arthritis Rheum,Vol. 48, No. 10, pp. (2898-902),

Timms, A. E., A. M. Crane, A. M. Sims, H. J. Cordell, L. A. Bradbury, A. Abbott, M. R. Coyne, O. Beynon, I. Herzberg, G. W. Duff, A. Calin, L. R. Cardon, B. P. Wordsworth \& M. A. Brown. (2004). The interleukin 1 gene cluster contains a major susceptibility locus for ankylosing spondylitis. Am J Hum Genet,Vol. 75, No. 4, (Oct), pp. (587-95), 0002-9297 (Print), 0002-9297 (Linking)

Torigoe, K., S. Ushio, T. Okura, S. Kobayashi, M. Taniai, T. Kunikata, T. Murakami, O. Sanou, H. Kojima, M. Fujii, T. Ohta, M. Ikeda, H. Ikegami \& M. Kurimoto. (1997). Purification and characterization of the human interleukin-18 receptor. $J$ Biol Chem,Vol. 272, No. 41, (Oct 10), pp. (25737-42), 0021-9258 (Print), 0021-9258 (Linking)

Tsui, F. W., H. W. Tsui, E. Y. Cheng, M. Stone, U. Payne, J. D. Reveille, M. J. Shulman \& A. D. I. Paterson, R D. (2003). Novel genetic markers in the 5'-flanking region of ANKH are associated with ankylosing spondylitis. Arthritis Rheum,Vol. 48, No. 3, pp. (791-7),

Tsui, F. W., N. Haroon, J. D. Reveille, P. Rahman, B. Chiu, H. W. Tsui \& R. D. Inman. (2010). Association of an ERAP1 ERAP2 haplotype with familial ankylosing spondylitis. Ann Rheum Dis,Vol. 69, No. 4, (Apr), pp. (733-6), 1468-2060 (Electronic), 0003-4967 (Linking) 
Tsui, H. W., R. D. Inman, A. D. Paterson, J. D. Reveille \& T. FW. (2005). ANKH variants associated with ankylosing spondylitis: gender differences. Arthritis Res Ther,Vol. 7, No. 3, pp. (513-25),

Tsui, H. W., R. D. Inman, J. D. Reveille \& F. W. Tsui. (2007). Association of a TNAP haplotype with ankylosing spondylitis. Arthritis Rheum,Vol. 56, No. 1, (Jan), pp. (234-43), 0004-3591 (Print), 0004-3591 (Linking)

van der Linden, S. M., H. A. Valkenburg, B. M. de Jongh \& A. Cats. (1984). The risk of developing ankylosing spondylitis in HLA-B27 positive individuals. A comparison of relatives of spondylitis patients with the general population. Arthritis Rheum. ,Vol. 27, No. 3, (March 1984), pp. (241-249),

van der Paardt, M., J. B. Crusius, M. A. Garcia-Gonzalez, P. Baudoin, P. J. Kostense, B. Z. Alizadeh, B. A. Dijkmans, A. S. Pena \& I. E. van der Horst-Bruinsma. (2002). Interleukin-1beta and interleukin-1 receptor antagonist gene polymorphisms in ankylosing spondylitis. Rheumatology (Oxford),Vol. 41, No. 12, (Dec), pp. (1419-23), 1462-0324 (Print), 1462-0324 (Linking)

van der Paardt, M., J. B. Crusius, M. H. de Koning, S. A. Morre, R. J. van de Stadt, B. A. Dijkmans, A. S. Pena \& I. E. van der Horst-Bruinsma. (2005a). No evidence for involvement of the Toll-like receptor 4 (TLR4) A896G and CD14-C260T polymorphisms in susceptibility to ankylosing spondylitis. Ann Rheum Dis,Vol. 64, No. 2, (Feb), pp. (235-8), 0003-4967 (Print), 0003-4967 (Linking)

van der Paardt, M., J. B. Crusius, M. A. Garcia-Gonzalez, B. A. Dijkmans, A. S. Pena \& I. E. van der Horst-Bruinsma. (2005b). Susceptibility to ankylosing spondylitis: no evidence for the involvement of transforming growth factor beta 1 (TGFB1) gene polymorphisms. Ann Rheum Dis,Vol. 64, No. 4, (Apr), pp. (616-9), 0003-4967 (Print), 0003-4967 (Linking)

Vargas-Alarcon, G., J. D. Londono, G. Hernandez-Pacheco, C. Pacheco-Tena, E. Castillo, M. H. Cardiel, J. Granados \& R. Burgos-Vargas. (2002). Effect of HLA-B and HLA-DR genes on susceptibility to and severity of spondyloarthropathies in Mexican patients. Ann Rheum Dis,Vol. 61, No. 8, (Aug), pp. (714-717), 0003-4967 (Print), 0003-4967 (Linking)

Vargas-Alarcón, G., A. Garcia, S. Bahena, H. Melin-Aldana, F. Andrade, G. Ibañez-de-Kasep, J. Alcocer-Varela, D. Alarcón-Segovia \& J. Granados. (1994). HLA-B alleles and complotypes in Mexican patients with seronegative spondyloarthropathies. Ann Rheum Dis,Vol. 53, No. 11, (November 1994), pp. (755-758),

Venter, J. C., M. D. Adams, E. W. Myers, P. W. Li, R. J. Mural, G. G. Sutton, H. O. Smith, M. Yandell, C. A. Evans, R. A. Holt, J. D. Gocayne, P. Amanatides, R. M. Ballew, D. H. Huson, J. R. Wortman, Q. Zhang, C. D. Kodira, X. H. Zheng, L. Chen, M. Skupski, G. Subramanian, P. D. Thomas, J. Zhang, G. L. Gabor Miklos, C. Nelson, S. Broder, A. G. Clark, J. Nadeau, V. A. McKusick, N. Zinder, A. J. Levine, R. J. Roberts, M. Simon, C. Slayman, M. Hunkapiller, R. Bolanos, A. Delcher, I. Dew, D. Fasulo, M. Flanigan, L. Florea, A. Halpern, S. Hannenhalli, S. Kravitz, S. Levy, C. Mobarry, K. Reinert, K. Remington, J. Abu-Threideh, E. Beasley, K. Biddick, V. Bonazzi, R. Brandon, M. Cargill, I. Chandramouliswaran, R. Charlab, K. Chaturvedi, Z. Deng, V. Di Francesco, P. Dunn, K. Eilbeck, C. Evangelista, A. E. Gabrielian, W. Gan, W. Ge, F. Gong, Z. Gu, P. Guan, T. J. Heiman, M. E. Higgins, R. R. Ji, Z. Ke, K. A. Ketchum, Z. Lai, Y. Lei, Z. Li, J. Li, Y. Liang, X. Lin, F. Lu, G. V. Merkulov, N. Milshina, H. M. Moore, A. K. Naik, V. A. Narayan, B. Neelam, D. Nusskern, D. B. Rusch, S. Salzberg, W. Shao, B. Shue, J. Sun, Z. Wang, A. Wang, X. Wang, J. Wang, 
M. Wei, R. Wides, C. Xiao, C. Yan, et al. (2001). The sequence of the human genome. Science,Vol. 291, No. 5507, (Feb 16), pp. (1304-51), 0036-8075 (Print), 00368075 (Linking)

Wang, X., J. Huang, Z. Lin, Z. Liao, C. Li, Q. Wei, Y. Jiang, L. Zhao \& J. Gu. (2010). Singlenucleotide polymorphisms and expression of IL23R in Chinese ankylosing spondylitis patients. Rheumatol Int,Vol. 30, No. 7, (May), pp. (955-9), 1437-160X (Electronic), 0172-8172 (Linking)

Wei, J. C., W. C. Tsai, H. S. Lin, C. Y. Tsai \& C. T. Chou. (2004). HLA-B60 and B61 are strongly associated with ankylosing spondylitis in HLA-B27-negative Taiwan Chinese patients. Rheumatology,Vol. 43, No. 7, (Jun 2004), pp. (839-42),

$\mathrm{Wu}, \mathrm{Z}$. \& J. R. Gu. (2007). A meta-analysis on interleukin-1 gene cluster polymorphism and genetic susceptibility for ankylosing spondylitis. Zhonghua Yi Xue Za Zhi,Vol. 87, No. 7, (Feb 13), pp. (433-7), 0376-2491 (Print), 0376-2491 (Linking)

Yamaguchi, A., N. Tsuchiya, H. Mitsui, M. Shiota, A. Ogawa, K. Tokunaga, S. Yoshinoya, T. Juji \& K. Ito. (1995). Association of HLA-B39 with HLA-B27-negative ankylosing spondylitis and pauciarticular juvenile rheumatoid arthritis in Japanese patients. Evidence for a role of the peptide-anchoring B pocket. Arthritis Rheum,Vol. 38, No. 11, (November 1995), pp. (1672-1677),

Yamazaki, K., D. McGovern, J. Ragoussis, M. Paolucci, H. Butler, D. Jewell, L. Cardon, M. Takazoe, T. Tanaka, T. Ichimori, S. Saito, A. Sekine, A. Iida, A. Takahashi, T. Tsunoda, M. Lathrop \& Y. Nakamura. (2005). Single nucleotide polymorphisms in TNFSF15 confer susceptibility to Crohn's disease. Hum Mol Genet,Vol. 14, No. 22, (Nov 15), pp. (3499-506), 0964-6906 (Print), 0964-6906 (Linking)

York, I. A., S. C. Chang, T. Saric, J. A. Keys, J. M. Favreau, A. L. Goldberg \& K. L. Rock. (2002). The ER aminopeptidase ERAP1 enhances or limits antigen presentation by trimming epitopes to 8-9 residues. Nat Immunol,Vol. 3, No. 12, (Dec), pp. (1177-84), 1529-2908 (Print), 1529-2908 (Linking)

Yue, T. L., J. Ni, A. M. Romanic, J. L. Gu, P. Keller, C. Wang, S. Kumar, G. L. Yu, T. K. Hart, X. Wang, Z. Xia, W. E. DeWolf, Jr. \& G. Z. Feuerstein. (1999). TL1, a novel tumor necrosis factor-like cytokine, induces apoptosis in endothelial cells. Involvement of activation of stress protein kinases (stress-activated protein kinase and p38 mitogen-activated protein kinase) and caspase-3-like protease. J Biol Chem,Vol. 274, No. 3, (Jan 15), pp. (1479-86), 0021-9258

Zinovieva, E., C. Bourgain, A. Kadi, F. Letourneur, B. Izac, R. Said-Nahal, N. Lebrun, N. Cagnard, A. Vigier, S. Jacques, C. Miceli-Richard, H. J. Garchon, S. Heath, C. Charon, D. Bacq, A. Boland, D. Zelenika, G. Chiocchia \& M. Breban. (2009). Comprehensive linkage and association analyses identify haplotype, near to the TNFSF15 gene, significantly associated with spondyloarthritis. PLoS Genet,Vol. 5, No. 6, (Jun), 1553-7390 


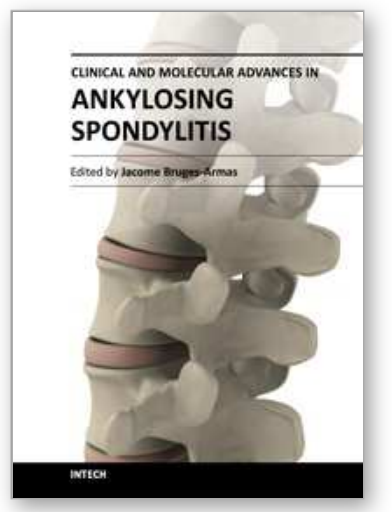

\author{
Clinical and Molecular Advances in Ankylosing Spondylitis \\ Edited by Dr. Jacome Bruges-Armas
}

ISBN 978-953-51-0137-6

Hard cover, 164 pages

Publisher InTech

Published online 22, February, 2012

Published in print edition February, 2012

The first section of the book entitled Clinical and Molecular Advances in Ankylosing Spondylitis is a review of the clinical manifestations of Ankylosing Spondylitis (AS) and Spondyloarthritis (SpA). The book includes chapters on Bone Mineral Density measurements, two chapters on the temporomandibular joints, axial fractures, clinical manifestations, diagnosis, and treatment. Molecular genetics and immune response are analyzed in the second section of the book; information on HLA-B*27, other MHC genes and the immune response of AS patients to bacteria is reviewed and updated. Two chapters are dedicated to recent information on non-MHC genes in AS susceptibility, and to new data on disease pathways generated from gene expression studies on peripheral blood.

\title{
How to reference
}

In order to correctly reference this scholarly work, feel free to copy and paste the following:

Bruno Filipe Bettencourt, Iris Foroni, Ana Rita Couto, Manuela Lima and Jácome Bruges-Armas (2012). Genetics in Ankylosing Spondylitis - Beyond HLA-B*27, Clinical and Molecular Advances in Ankylosing Spondylitis, Dr. Jacome Bruges-Armas (Ed.), ISBN: 978-953-51-0137-6, InTech, Available from: http://www.intechopen.com/books/clinical-and-molecular-advances-in-ankylosing-spondylitis/genetics-inankylosing-spondylitis-beyond-hla-b-27

\section{INTECH}

open science | open minds

\author{
InTech Europe \\ University Campus STeP Ri \\ Slavka Krautzeka 83/A \\ 51000 Rijeka, Croatia \\ Phone: +385 (51) 770447 \\ Fax: +385 (51) 686166 \\ www.intechopen.com
}

\author{
InTech China \\ Unit 405, Office Block, Hotel Equatorial Shanghai \\ No.65, Yan An Road (West), Shanghai, 200040, China \\ 中国上海市延安西路65号上海国际贵都大饭店办公楼405单元 \\ Phone: +86-21-62489820 \\ Fax: +86-21-62489821
}


(C) 2012 The Author(s). Licensee IntechOpen. This is an open access article distributed under the terms of the Creative Commons Attribution 3.0 License, which permits unrestricted use, distribution, and reproduction in any medium, provided the original work is properly cited. 